NBER WORKING PAPER SERIES

\title{
WHY DO HOUSEHOLDS WITHOUT CHILDREN SUPPORT LOCAL PUBLIC SCHOOLS?
}

\author{
Christian A. L. Hilber \\ Christopher Mayer \\ Working Paper 10804 \\ http://www.nber.org/papers/w10804
NATIONAL BUREAU OF ECONOMIC RESEARCH 1050 Massachusetts Avenue
Cambridge, MA 02138
September 2004

We thank Gilles Duranton, Harold Elder, William Fischel, Joe Gyourko, Caroline Hoxby, Bob Inman, Loretta Mester, Wallace Oates, Todd Sinai, William Strange and seminar participants at the ASSA meetings, the NBER meetings, the Public Choice meetings, the Wharton School, and Federal Reserve Bank of Philadelphia for helpful comments. We also thank the Wharton GIS Lab and Susan Wachter and Paul Amos for providing data used in the paper. Any errors, of course, are our own. Financial assistance from the Swiss National Science Foundation, the Max Geldner Foundation, the Zell/Lurie Real Estate Center at Wharton, and the Milstein Center for Real Estate at Columbia Business School is gratefully acknowledged.The views expressed herein are those of the author(s) and not necessarily those of the National Bureau of Economic Research.

(C2004 by Christian A. L. Hilber and Christopher Mayer. All rights reserved. Short sections of text, not to exceed two paragraphs, may be quoted without explicit permission provided that full credit, including () notice, is given to the source. 
Why Do Households Without Children Support Local Public Schools?

Christian A. L. Hilber and Christopher Mayer

NBER Working Paper No. 10804

September 2004, Revised September 2006

JEL No. H4, H7, I2, R31

\begin{abstract}
While residents receive similar benefits from many local government programs, only about one-third of all households have children in public schools. We argue that capitalization of school spending into house prices can encourage residents to support spending on schools, even if the residents themselves will never have children in schools. We identify a proxy for the extent of capitalization - the supply of land available for new development - and show that in response to a plausibly exogenous spending shock in Massachusetts, towns with little undeveloped land have larger changes in house prices, but smaller changes in quantity (construction). Towns with little available land also spend more on schools. We extend these results using data from school districts in 46 states, showing that per pupil spending is positively related to the percentage of developed land. This positive correlation persists only in districts where the median resident is a homeowner and is stronger in districts with more elderly residents who do not use school services and have a shorter expected duration in their home. These findings support models in which house price capitalization encourages more efficient provision of public services and may explain why some elderly residents support school spending.
\end{abstract}

Christian A. L. Hilber

London School of Economics and Political

Science

Houghton Street

London WC2A 2AE

United Kingdom

c.hilber@1se.ac.uk
Christopher J. Mayer

Columbia Business School

Uris Hall \#808

3022 Broadway

New York, NY 10027

and NBER

cm310@columbia.edu 
School spending is the subject of some of the most contentious debates in local government. While many residents benefit relatively equally from expenditures on police and fire services or plowing the streets, only about one-third of all households have children in public schools. ${ }^{1}$ Although altruism may drive some voters without children to support public schools, one might expect that many communities will "underprovide" education from the perspective of an individual that considers demand for education over his entire lifecycle.

A countervailing argument is that good schools are an amenity that is capitalized into house prices. Past research strongly supports the proposition that good schools are capitalized into house prices. ${ }^{2}$ Even if a voter does not use the schools, a future buyer of the property may care about school quality. Thus childless residents may vote in favor of school spending to maximize home values. Yet the extent of house price capitalization varies across communities. House prices may respond more strongly to a spending change in towns where land for new residential construction is scarce. Thus residents in such towns have an additional incentive to support school spending.

Previous theoretical work supports this proposition. Brueckner and Joo (1991) show that in a world with imperfectly mobile residents, the voter's ideal spending level for durable local public goods reflects a blend of his or her own preferences and those of the eventual buyer of the house. Data from the American Housing Survey shows that the median homebuyer outside of central cities has school-aged children although the median resident does not. This link may explain why some voters without children, such as the elderly, might still support additional school spending.

\footnotetext{
${ }^{1}$ The 1990 U.S. Census shows that 36 percent of households have children below 18 years. The National Household Education Survey estimates that 91 percent of grade 3-12 students were enrolled in public schools in 1993.

${ }^{2}$ See Barrow and Rouse (2004), Black (1999), Bogart and Cromwell (1997, 2000), Cheshire and Sheppard (2004), Dee (2000), and Weimer and Wolkoff (2001).
} 
In the prototypical Tiebout (1956) world, residents would perfectly sort into the community with their exact preferences. Older households would move to communities that focus exclusively on services for the elderly. However, with a finite number of communities, multidimensional preferences, and moving costs, residents often live in communities whose mix of services don't match their precise preferences. Elderly households may live in a community with good schools and high school spending because they are long-time residents or because that town has other desirable amenities besides the schools.

Previous research has sometimes, but not always found that educational spending is negatively correlated with the percentage of elderly residents. ${ }^{3}$ Harris et al. (2001) show that percent of elderly has only a modest negative effect on local school spending, but a strong negative effect on state spending. They argue that the difference is due to the fact that state spending is not perceived as having any impact on house prices, while local spending matters more for house prices. Similarly, Bergstrom et al. (1982) present evidence from a Michigan survey of elderly voters showing unusual support for school spending, speculating that such support might be driven by the observation that many of these voters planned on selling their house soon and that bad schools bring down house prices.

To examine the hypothesis that the extent of house price capitalization drives expenditures on schools, we examine communities that differ in their relative availability of undeveloped residential land. This link is quite intuitive. As long as the local supply curve of land available for housing is upward sloping and communities are not perfect substitutes, both price and quantity will adjust in response to demand shocks. However, price adjustment should be larger (and quantity adjustment smaller) in places with less available land for development. This

\footnotetext{
${ }^{3}$ See Inman (1978), Cutler et al. (1993), Poterba (1997), Hoxby (1998), Goldin and Katz (1997, 1999), and Alesina et al. (1999).
} 
argument is at odds with the assumption in other research that local property values fully reflect the present discounted value of future taxes and benefits. Such an approach depends on demand factors alone and assumes that the supply of undeveloped land is inelastic and similar across locations. Only a few studies consider the possibility of variation in the supply elasticity among different locations (e.g., Malpezzi 1996 and Harter-Dreiman 2004) or the effect of differential land supply elasticity on the extent of capitalization (Bruce and Holtz-Eakin 1999).

We present evidence in favor of this hypothesis using two different data sources. First, we expand on the empirical framework in Bradbury et al. (2001), who use variation from a property tax limit in Massachusetts to generate exogenous instruments for spending changes across communities. When we divide their sample into two parts based on the extent to which towns have available undeveloped land, we find that demand shocks lead to larger changes in house prices and smaller changes in quantity in locations with little undeveloped land. These land constrained communities also vote to increase school spending at a faster rate.

Next, we use data on school districts in 46 states to show that per-pupil spending is strongly and positively related to the percentage of developed land in a school district, a proxy for supply inelasticity. The coefficients suggest that a school district with little available land for development (68.1 percent of potentially developable land is already used for housing) spends roughly 10 percent more per pupil on schools, all else equal, than a district with a large amount of land available for development (6.6 percent developed land). Given the likelihood that land availability is correlated with other factors that might impact school spending, we examine a number of interactions that are driven by theory linking house price capitalization to school spending. For example, the positive correlation between school spending and the percentage of developed land only exists in communities where more than one-half of households are homeowners. In addition, the percent of elderly residents is positively related to per-pupil school 
spending in districts with little available land, but percent of elderly residents is unrelated or negatively related to school spending in districts where land for construction is more easily available. This effect is even more pronounced for older elderly residents who have a shorter expected duration in their property. These results support our proposition that spending on schools is higher in places with more house price capitalization.

These empirical findings have implications for theoretical and empirical studies in a variety of areas. For example, the capitalization of durable local public goods into property values can induce local governments to behave efficiently (e.g., Edelson 1976, Sonstelie and Portney 1978, and Fischel 2001) and provides a mechanism so that present generations internalize the wellbeing of future generations (e.g., Oates and Schwab 1988, 1996, Glaeser 1996, and Conley and Rangel 2001). Fischel (2001) describes homeowners as "homevoters" whose voting and local political activities are guided by their concerns about home values. Our results support such normative implications in locations with limited opportunities for new construction, but not for places where land for development is freely available.

Finally, research in many areas makes the implicit assumption of uniform capitalization, including urban quality-of-life comparisons ${ }^{4}$ and capitalization studies of environmental amenities, ${ }^{5}$ school spending (or school quality), ${ }^{6}$ government subsidies, ${ }^{7}$ and taxes. ${ }^{8}$ Such conclusions may be inaccurate given that the extent of capitalization varies across jurisdictions, for example, due to differences in the extent of land-use regulation (Mayer and Somerville 2000

\footnotetext{
${ }^{4}$ See Blomquist et al. (1988), Gyourko and Tracy (1991), and a summary by Gyourko et al. (1999).

${ }^{5}$ See, for example, the meta-analysis by Smith and Huang (1995) or recent work by Bui and Mayer (2003).

${ }^{6}$ While Black (1999) looks only at houses very close to attendance district boundaries where land supply might indeed be equally and completely inelastic, Haurin and Brasington (1996) and Dee (2000) present estimates based on much less disaggregated data, which might be biased without controlling for land supply.

${ }^{7}$ Several authors have argued that location-based aid (as opposed to grants to poor individuals) can have adverse consequences, since poor residents are typically renters who will be forced to pay higher rents if the transfers are capitalized into higher house prices (e.g., Hamilton 1976 and Wyckoff 1995).
} 
and Hwang and Quigley 2004). Our findings suggest that house price capitalization estimates cannot be easily interpreted as a household's willingness to pay for amenities when land for new development is readily available, as is often true outside of coastal areas in the US.

\section{Theoretical Framework}

In the analysis that follows, we argue that the extent of capitalization of fiscal variables and amenities into house prices should be particularly high in places where supply of land for new residential construction is relatively inelastic. Some have argued that as long as boundaries do not change, land supply must always be completely inelastic. Yet the amount of developable land for housing is not fixed because land has an opportunity cost that depends on its previous use such as farming or lower density residential development (Novy-Marx 2004).

\subsection{Land Supply Elasticity and House Price Capitalization}

It is intuitive that both price and quantity will adjust in response to demand shocks and that the price adjustment will be larger (and quantity adjustment smaller) if land supply is relatively inelastic. This argument is illustrated in Figure 1. The figure depicts a residential land market with an upward-sloping land supply curve. Land must always be valued above the reservation price $p_{F}$, which we think of as the present value of future land rents from farming. As residential land values rise, more land (L) becomes developed for housing.

\footnotetext{
${ }^{8}$ Variation in the extent of capitalization may lead to differences in homeowner benefits from the mortgage interest deduction and other federal taxes and subsidies. See Capozza et al. (1996), Stull and Stull (1991), Man and Bell (1996), and Palmon and Smith (1998a, b).
} 
Figure 1: Exogenous Demand Shocks in a Community with Plenty and Little Available Land

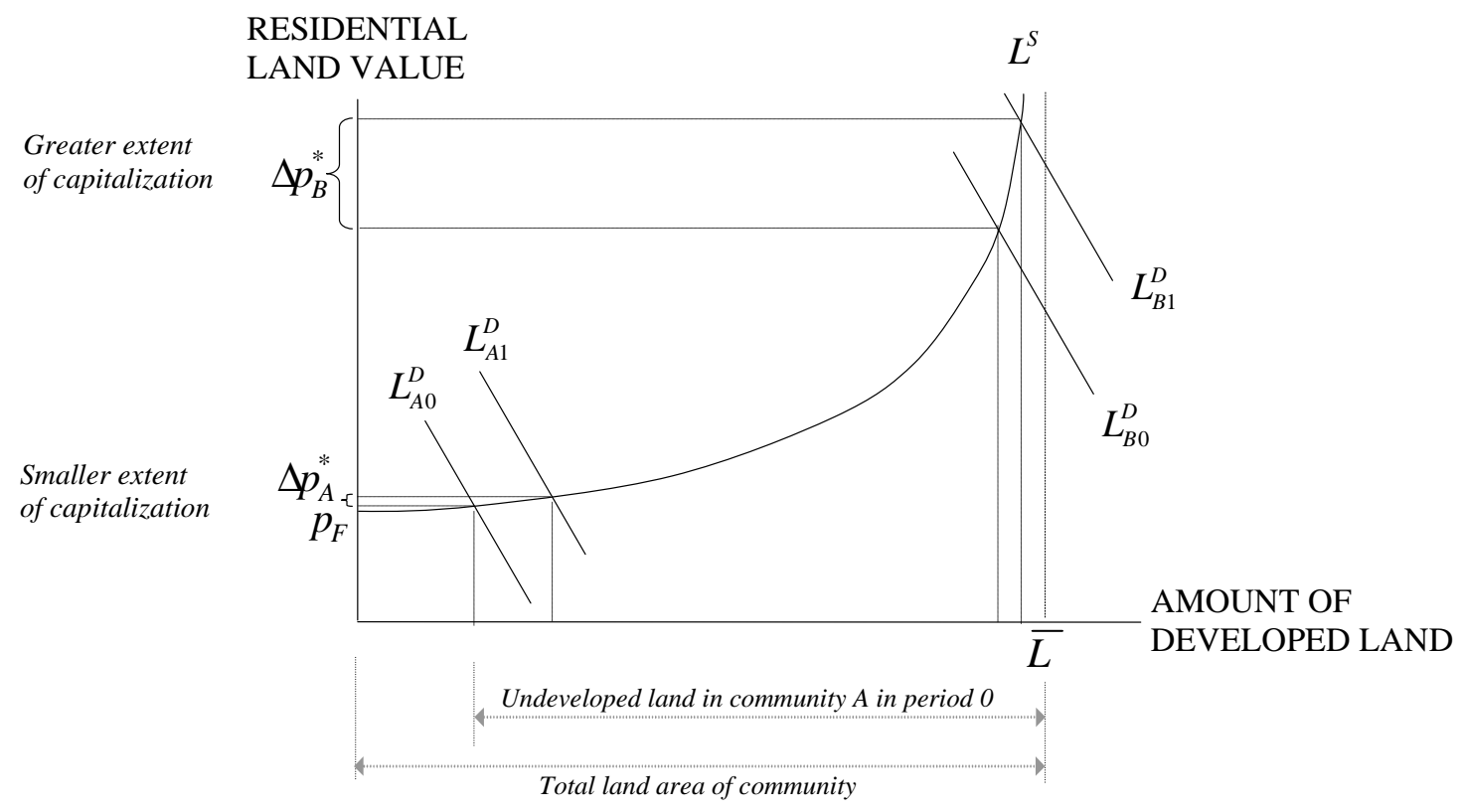

As in the models of Capozza and Helsley (1989 and 1990) and Novy-Marx (2004), when a community becomes increasingly built-up, the incremental "cost" of building an additional housing unit increases. The intuition is straightforward. Initially, owners will convert land to residential use that has other low-value uses, such as farming or parking lots. Eventually, builders must convert land that is being used for relatively high-value purposes. In addition, by building today, owners forgo the option to redevelop land in the future when undeveloped land may have even higher value. Hence the hurdle rate required to exercise the development option rises quickly when there is little remaining undeveloped land.

Previous research on zoning provides further evidence in favor of an upward-sloping supply curve for residential land in a given community. Pogodzinski and Sass (1994) show that land-use regulations appear to "follow the market," after controlling for selection bias. Fischel (1985) and Rudel (1989) argue that undeveloped land can be relatively easily converted into residential use in rural areas and locations at the edge of cities but not in more developed places 
such as large urban and suburban communities, where existing residents have relatively strong incentives to pass restrictive zoning measures and thereby effectively limit supply.

In the empirical work that follows, we use the amount of available developable land in a community as a proxy for the residential land supply elasticity. The rationale for that choice is illustrated in Figure 1. Suppose that all communities in a specific region have an identical land area $\bar{L}$ and residential land supply curve $L^{S}$, but that one locality, community A, has had little previous residential development and is on a very elastic portion of the residential land supply curve, while community $\mathrm{B}$, with a lot of residential development, is on the inelastic part of the supply curve. As the figure indicates, an exogenous demand shock will have a stronger price effect (and a smaller increase in new construction) in community A, with a higher percentage of already developed land, than in community B, with much less developed land.

Several papers provide empirical support for our theoretical framework. Mayer and Somerville (2000) show that land supply elasticities vary across MSAs, with MSA housing permits exhibiting a lower responsiveness to prices in more highly-regulated markets. Hwang and Quigley (2004) obtain similar findings. Brasington (2002) provides evidence that capitalization of schooling and crime is weaker toward the edge of an urban area where housing supply elasticities and developer activity are greater.

\subsection{A Property Tax Limit as an Exogenous Demand Shock}

Brueckner (1982) notes that if local governments provide local public goods in a propertyvalue-maximizing fashion, they will choose a spending level such that the marginal benefit of an extra dollar of spending will be exactly offset by the marginal cost of the property taxes needed to finance that spending. Brueckner's argument is illustrated in Figure 2 for the simple case where aggregate property values are a single-peaked function of a local public good $g$. Spending to the left of the peak signifies underprovision, while spending to the right of the peak is too much. 


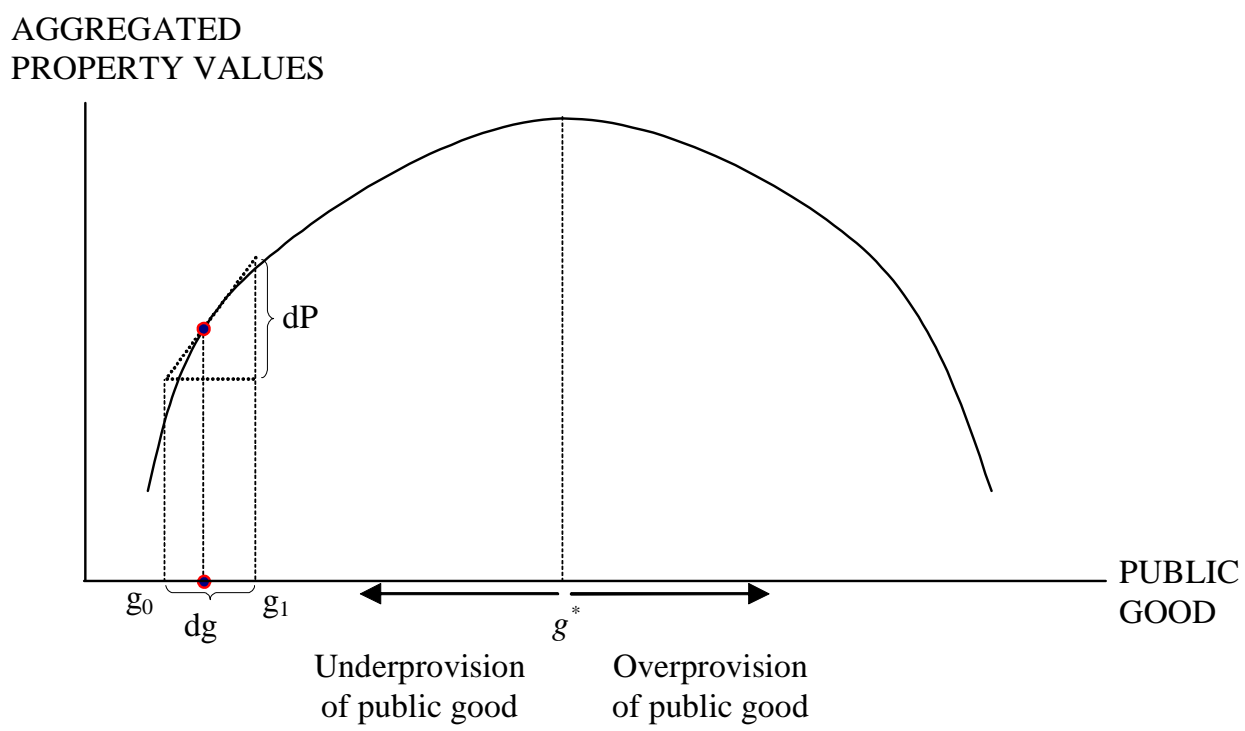

We use this framework to analyze the effect of a tax reform that limits the flexibility of individual communities to choose their desired level of property taxes, as was approved in states such as California, Michigan, and Massachusetts in the 1970s and 1980s. Sponsors claimed that entrenched local officials spent more on public services than the residents wanted. The existence of a property tax limit will increase the utility of homeowners if spending were to the right of $\mathrm{g}^{*}$, such that $\partial P / \partial g<0$. However, if the tax limit restricts the local government from increasing spending to the optimal level, that is, $\partial P / \partial g>0$, the utility of homeowners is decreased in restricted towns. In this case, restricted towns can realize gains in property values if they can overcome the tax limit.

We examine the impact of Proposition 2⿺辶⿸厃㔾 in Massachusetts, approved in November 1980, as a specific example of such a tax reform. Proposition $2 \frac{1}{2}$ limited local municipal spending such that: 1) effective property tax rates were capped at 2.5 percent and 2) nominal annual growth in property tax revenues was limited to 2.5 percent, unless residents passed a referendum (called an “override”) allowing a greater increase. Spending rules under Proposition $2 \frac{1}{2}$ applied equally to 
all cities and towns, yet variations in local conditions at the time of its passage have led the measure to have a very different impact across communities.

Bradbury et al. (2001) measure the impact of spending changes on housing values using the tax reform to provide instruments for local changes in spending that are unrelated to changes in property values. In 1990, 224 out of 351 communities were at their levy limit, so that the only way to increase nominal spending by more than 2.5 percent per year was for residents to pass an override. Bradbury et al. show that Proposition $2 \frac{1}{2}$ significantly constrained local spending in some communities, with most of its impact on school spending. Constrained towns realized gains in house prices to the degree that they were able to increase school spending despite the limitation. Changes in non-school spending had little impact on home values. The authors speculate that the marginal homebuyer may place a higher value on school spending than the median voter, possibly because homebuyers are more likely to have school-aged children. That communities were able to realize gains in property values to the extent that they were able to increase spending in spite of the limitation suggests that Proposition $2 \frac{1}{2}$ caused many towns to under-provide local public education, at least from the perspective of the marginal homebuyer.

We expect that communities which increased spending despite Proposition $2 \frac{1}{2} 2$ should have realized stronger gains in property values if their land supply curve is inelastic rather than elastic. This effect is illustrated in Figure 3. 


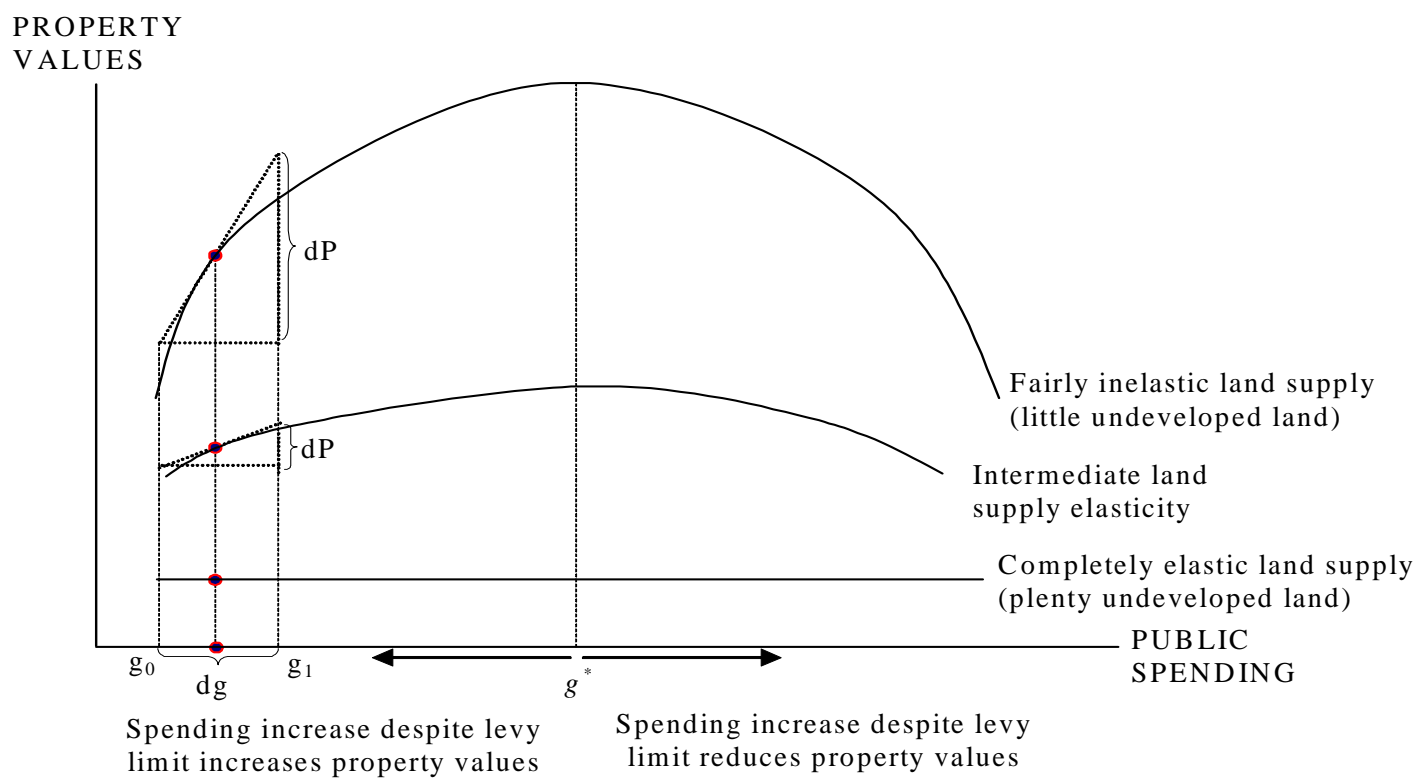

The figure shows the effect of a property tax limit on property values for various degrees of land supply elasticity (completely elastic, intermediate elasticity, fairly inelastic). Consider a specific community that is constrained by Proposition $2 \frac{1}{2}$ and can only provide $g_{0}<g^{*}$. The fiscal distortion induced by the property tax limit results in lower property values. If the community increases the public spending level despite the limitation to $g_{1}$ it realizes gains in property values that depend on the land supply elasticity. ${ }^{9}$ A town with inelastic land supply will have a greater increase in property values than a community with more elastic land supply. ${ }^{10}$

Of course, this framework assumes that some portion of current spending affects the utility level of future residents. This assumption holds if a school district purchases durable goods that benefit future residents, or if current spending decisions represent a signal or commitment to

\footnotetext{
${ }^{9}$ The price level of the three curves is arbitrary. However, rural communities that have elastic land supply consist of inexpensive farmland while suburban and urban communities with inelastic supply of land typically have scarce amenities and more expensive residential land.

${ }^{10}$ Figure 3 also implies that spending increases despite Proposition $2 \frac{1}{2}$ lead to smaller gains in property values in communities that are closer to the optimum. In this context it is important to point out that the likelihood of being constrained by Proposition $2 \frac{1}{2} 2$ is not related to land availability (see the empirical analysis below for evidence).
} 
future spending. For Proposition 21/2, most increases in the levy limit are permanent; so if voters choose to increase the spending limit in one year, they are choosing to increase that limit in all future years as well.

\section{Empirical Analysis for Massachusetts}

The preceding section argues that house prices in towns constrained by a tax limit should change more strongly (and construction less strongly) in response to spending changes in areas with little available undeveloped land than in areas with plenty of undeveloped land. To the extent that increases in spending result in higher house prices, communities with little available land have an additional incentive to spend more money on schools. These communities should also be more willing to pass a referendum that approves additional school spending. We test these hypotheses using data from Massachusetts and the passage of Proposition 21/2.

This setting has several advantages. We estimate the impact of government spending on house values using a well-identified setting. Community characteristics from the date Proposition $2 \frac{1}{2} 2$ was passed in 1980 serve as instruments for otherwise endogenous spending changes 10 years later. By examining changes in spending we are able to difference away timeinvariant attributes that may be correlated with house prices or with our independent variables. Finally, we have very detailed data on land use in each community. We show that the amount of available land for development in a community serves as a good proxy for supply elasticity and that school spending is higher in communities with less remaining developable land.

\subsection{Empirical Specification}

We estimate the following system of equations:

$$
\begin{aligned}
& \Delta \text { price }=\alpha_{0}+\alpha_{1}(\text { construction })+\alpha_{2}(\Delta \text { spending })+\alpha_{3}(\text { demand shifters })+\varepsilon_{\mathrm{p}} \\
& \text { construction }=\beta_{0}+\beta_{1}(\Delta \text { price })+\beta_{2}(\text { supply shifters })+\varepsilon_{\mathrm{c}}
\end{aligned}
$$


$\Delta$ spending $=\gamma_{0}+\gamma_{1}(\Delta$ pupils $)+\gamma_{2}(\%$ developed land $)+\gamma_{3}($ spending shifters $)+\varepsilon_{\mathrm{sp}}$

$\Delta$ pupils $=\delta_{0}+\delta_{1}($ supply shifters $)+\delta_{2}($ demand shifters $)+\delta_{3}($ pupil shifters $)+\varepsilon_{\mathrm{pu}}$.

All of the bold variables in equations (1)-(4) are assumed to be endogenously determined. As in Mayer and Somerville (2000), we model new construction, the change in housing stock, as a function of the change in price and other supply variables. Demand, supply, spending, and pupil shifters are vectors of variables that also serve as instruments to separately identify coefficients in other equations. The exclusion restrictions across these equations are quite important. In the empirical section, we examine the results of loosening some of these restrictions.

We lay out the mechanisms through which capitalization impacts school spending with the following predictions:

Prediction 2A: The coefficients on changes in spending $\left(\alpha_{2}\right)$ and the demand shifters $\left(\alpha_{3}\right)$ in equation 1 (demand) will be larger in absolute value in towns with less available land for development (Figure 3).

Prediction $2 \mathrm{~B}$ : The price elasticity of construction $\left(\beta_{1}\right)$ in equation 2 (supply) will be smaller in places with less available land for development (Figure 1).

Predictions 2A and 2B suggest that demand shocks in locations with less available land should result in larger price changes, but less construction relative to places with more available land.

Prediction 2C: Communities with less available land for development increase school spending more in response to Proposition $2 \frac{1}{2}$. Spending increases have a larger impact on house prices in towns with less available undeveloped land and thus voters in these towns have stronger incentives to raise spending to maximize house prices.

To examine these predictions, we estimate equations (1)-(3) using two-stage least squares with instruments drawn from other equations. Our sample runs from 1990 to 1994, a time period 
when most Massachusetts communities were constrained by Proposition 21/2. We measure $\Delta$ price as the percentage change in single-family house prices from 1990-1994 for each community. Construction is the number of new single-family home permits issued between 1990 and 1994 divided by total existing housing units in each community. We disaggregate $\Delta$ spending into two parts, with separate variables for percentage change in school and non-school spending over the same period.

First consider equation (1). We use supply shifters from equation (2) and spending shifters from equation (3) as instruments for construction and $\Delta$ spending, respectively. As with Brueckner (1982), we interpret the coefficient on (change in) school spending as the net impact on house prices of spending another dollar on schools (or other public goods), taking into account the taxes necessary to pay for the additional spending.

Following Bradbury et al. (2001) and Case and Mayer (1996), we include three variables as demand shifters for housing in equation (1). These variables are based on previous work suggesting that aggregate shocks in demand have varied effects across local communities. For example, as Bradbury et al. (2001) document, the aging of the baby boom and the associated echo baby boom led to an increase in aggregate public school enrollments in Massachusetts since 1990. The resulting increase in the percentage of households who have children in public schools raised the demand for houses in towns with good quality schools relative to communities with poor quality schools. Thus we include average test scores as a proxy for differences in school quality across communities. As Case and Mayer (1996) show, the coefficient on this variable changes when aggregate enrollments are falling. We also include two dummy variables measuring a community's proximity to Boston to control for changes in the value of location during a period of increasing job growth in downtown Boston and the surrounding suburbs. 
The system of equations provides many instruments for $\Delta$ price in the construction equation, including the demand shifters, the spending shifters, and the pupil shifters. All of these variables impact price changes, directly or indirectly, by shifting demand, but not the supply of new units. The supply shifter in equation (2) is the lagged amount of new construction. We include lagged construction as an indication of the extent of regulation in various communities. One might be concerned that lagged construction is the least reliable of our instruments. The only specification where the supply shifter is necessary to separately identify a coefficient is in equation (1). Our findings are unaffected if we drop the construction variable and do not use the supply shifter as an instrument in this equation or if we drop the supply shifter as an instrument in other equations. We also estimate equation (2) over a relatively short 4-year period. To the extent that long-run supply is more elastic than short-run supply, our empirical work might overestimate the price effects and underestimate the quantity effects of a given demand shock. This may bias against finding any effect of land availability on capitalization and supply elasticities.

To test Predictions $2 \mathrm{~A}$ and $2 \mathrm{~B}$, we estimate equations (1) and (2) separately for communities with above- and below-median percentage of undeveloped land. Land availability comes from a 1984 University of Massachusetts aerial survey of the entire Commonwealth of Massachusetts. Land is classified into 21 uses. We measure the amount of developable land as the percentage of "open" or "undeveloped" land, which includes farmland. One might be concerned that this measure is endogenously determined, so that communities with stricter zoning rules also have more developable land, and vice versa. That is, some communities may have a lot of undeveloped land, but regulations limit new construction on that land. If true, we should find empirical evidence that communities with more developable land have a greater extent of house price capitalization. However, exactly the opposite is the case. 
We examine Prediction 2C by estimating equation (3) to see if school and non-school spending are related to land availability. As before, we use demand shifters, the supply shifter, and pupil shifters as instruments for the changes in the number of pupils in the school spending equation. The pupil shifter in equation (4) is the percentage of children under age 5 in 1990. This variable is correlated with expected demand for changes in school services, but is unrelated to resources to fund the schools under Proposition 21/2. However, excluding this variable from the housing demand equation (1) is less clear-cut. Our results are unchanged if we drop it when estimating equations (1) and (2). In the non-school spending equation, we measure change in demand for services with percentage change in the number of residents. We use the same instruments in the school and non-school spending equations.

Proposition $2 \frac{1 / 2}{2}$ provides a wealth of variables that are correlated with spending changes but are plausibly uncorrelated with housing supply or demand between 1990 and 1994. For consistency with Bradbury et al. (2001), we include all of these variables as spending shifters in our baseline specifications. (See Table 4 for the complete list of spending shifters used in the regressions.) Most variables are taken from the early 1980s prior to the passage of Proposition 21/2. However, a few variables are taken from the 1990 Census or state revenue data, including median family income, the nonresidential share of housing value, the ratio of school enrollments to population, and equalized property value per-capita. These variables are measures of community resources to support local schools or the political support for schools. However, one could argue that these variables might not be excludable from the housing demand equation. Thus when we estimate the house price regression, we include only the 1980 values of these variables as instruments, a time prior to the passage of Proposition $2 \frac{1}{2}$. The results are also littlechanged if we exclude these variables entirely. 
Finally, we provide additional evidence on Prediction $2 \mathrm{C}$ by examining the likelihood of passing an override for communities whose spending levels have reached their cap (the levy limit) under Proposition 21/2. This test may be the most directly applicable to the theory because constrained communities must go directly to the voters in order to pass an override. The independent variables in this specification are identical to those used in equation (3).

\subsection{Data}

Bradbury et al. (2001) provides a detailed description of the data on house prices, construction, land availability, community characteristics, school indicators, and fiscal condition. These variables are summarized in Table 1. Even during the relatively short 1990-94 time period, communities exhibit substantial variation in many of these variables. For example, although the average community increases school spending by 15 percent, individual towns had much larger positive and sometimes even negative changes in spending.

Case, Shiller, and Weiss, Inc. (CSW) provide house price indexes for 208 of the 351 communities in Massachusetts that are based on data from 135,000 pairs of sales drawn between 1982 and 1995. The communities with relatively few transactions that CSW drops from its data are small, often rural, communities that may have the most available land. This data limitation likely leads us to underestimate the impact of supply elasticity on capitalization because the smaller communities are likely to exhibit the smallest degree of house price capitalization.

\subsection{Results}

\section{A. Land Supply and Extent of Capitalization}

To begin, we estimate equation (1) separately for communities with above- and belowmedian percentage of available developable land (Table 2). The results are consistent with the prediction that communities with less available land have a greater extent of capitalization. 
All of the coefficients in the house price equation for communities with little available developable land (column (1)) are larger in absolute value than the coefficients in towns with more available land (column (2)). Of particular interest, the coefficient on changes in school spending is more than three times larger $(0.33$ versus 0.10$)$ in the towns with the least percentage of developable land and is only statistically significantly different from zero in those communities. As with Bradbury et al. (2001), the coefficient on changes in non-school spending is not statistically significant in either regression, though it is larger in the first column than the second one. Good commuting locations in the Boston MSA and the suburban ring and better quality school districts also became relatively more valuable in communities with little available land. Finally, price changes with respect to construction are much larger in communities with less developable land. An F-test rejects the hypothesis that the coefficients on the spending and demand variables are equal in columns (1) and (2) (p-value $=0.03)$.

As mentioned above, we include a broad set of instruments in our base specification for comparability with previous research. Yet one might wonder whether all of these instruments are truly exogenous or whether we are over-fitting the data, and in particular, whether some of the instruments may be correlated with the percentage of undeveloped land, an issue that would not have concerned previous researchers. To examine these possibilities, we re-run our specification removing as instruments six variables that are correlated with the percentage of undeveloped land with a p-value of at least 10-percent. Most obviously, the non-residential share of property value in 1980 may be difficult to separate from the percentage of land that is developed. An additional four of those instruments are measures of wealth or income, which might also be related to the extent of development or housing demand in a community due to political economy (voters want 
to protect property values) or community desirability. ${ }^{11}$ The final instrument in this category, the percentage of residents less than 5-years old in 1990, only has a p-value of 0.10 , but we exclude it for consistency.

The sensitivity tests continue to suggest that communities with less available land have a greater extent of capitalization. When we drop the six potentially troublesome instruments, the results become somewhat stronger than those presented in Table 2. The difference in the coefficients on the capitalization of school spending for more and less developed communities is larger in magnitude ( 0.45 vs -0.08 ), while the difference in other coefficients remains similar. Hansen's J-Statistic, a joint test of exogeneity of the instruments, has a p-value of 0.45 when we exclude the six troubling instruments, suggesting we cannot reject exogeneity. The findings also do not change if we re-estimate the equation by removing over-identified instruments one at a time. Finally, we estimate the equations with a minimal set of instruments that have no demographic characteristics or recent Proposition 21/2 variables, including lagged permits, the 1980 tax rate, and the number of years required to reduce tax rates to $2 \frac{1}{2} 2$ percent. With the small set of instruments, the coefficients are quite similar to those in Table 2, although the standard errors rise such that some of the endogenous variables are no longer statistically significant.

Table 3 examines differences in land supply elasticities between the same two groups of communities. Consistent with the second prediction from our theory, the evidence shows that shocks to demand lead to greater construction in towns with more available land. The dependent variable is the number of single-family home permits divided by total housing units. Columns (1a) and (1b) report direct estimates of land supply elasticities. The coefficient on change in house prices is relatively large and significant at the 5 percent level in locations with more

\footnotetext{
${ }^{11}$ These instruments include per-capita property value in 1980, per-capita income in 1980, the proportion of state aid in the local budget in 1981, and the percent of adults with a college education in 1980 .
} 
developable land, while it is quite small and not statistically significant in the more developed locations. The test of equality between the coefficients in columns (1a) and (1b) rejects with a pvalue of 0.10 . Columns (2a) and (2b) include lagged permits to control for other factors that might lead to new construction. We exclude this variable in the first specification out of concerns that it might not be truly exogenous. Even with its inclusion, the coefficient on change in house prices is about one third larger in locations with more available land. A test of equality between the coefficients in columns (2a) and (2b) rejects with a p-value of 0.10 . The regression constants suggest that steady-state construction is one-half as large in relatively developed regions. ${ }^{12}$

\section{B. Spending and Override Regression Results}

The findings in the previous section suggest that locations with little available land for development respond to demand shocks with relatively larger changes in house prices and smaller changes in new construction. Next, we examine whether communities with little available land have a disproportionate increase in spending on public services when faced with a shock to school spending due to Proposition 21/2.

Table 4 reports regression estimates from the equations for percentage change in school spending and non-school spending between 1990 and 1994 for all communities in our sample. To control for differences in the usage of local services, the school spending regressions include the percent change in number of students as an endogenous variable, while the non-school spending regressions include the percent change in population between 1990 and 1994 . We include exogenous variables from the housing demand and supply equations in Tables 2 and 3 as instruments for percent change in pupils or population. Columns (1) and (2) report the equations with all of the variables described in the data section, a broad set of constraint variables from

\footnotetext{
${ }^{12}$ Our estimated supply elasticities are much lower than in other work that looks at longer time periods. See Gyourko and Voith 2000, for example.
} 
Proposition $2 \frac{1}{2}$, plus the percentage of developed land, the variable of interest. The results are virtually unchanged in columns (3) and (4) when we drop the more recent variables.

As suggested by Prediction 2C, land scarcity has a positive effect on school spending. The coefficient on percentage of developed land is statistically significant at the 5 percent level and is quite similar across specifications (columns 1 and 3). The coefficient in column (1) suggests that a community with 10 percent more developed land in 1984 has a 2.4 percent larger increase in school spending. Cities and towns that were required to cut revenues for the first two or three years of Proposition 21/2 (the communities that faced the largest initial constraints) increased their school spending 9 and 16 percentage points less, respectively, than communities with zero or one year of initial revenue cuts. All of the Proposition $2 \frac{1}{2}$ coefficients but one (at levy limit, no overrides) have the anticipated sign, and many variables are statistically different from zero.

The non-school spending results are much weaker, although still in line with our prediction. The coefficient on percentage of developed land is positive, but not statistically different from zero. Only three other constraint variables are individually statistically significant, with the coefficient on at levy limit in 1989, no overrides again having the wrong sign. These findings are consistent with those in Bradbury et al. (2001), who speculate that non-school spending, which is dominated by costs for fire, police, and public works such as trash removal, street repair, and snow plows, may have fewer discretionary items than the school budget.

Finally, we examine the relationship between land availability and the cumulative amount of overrides (per capita) in the communities that were most highly constrained by Proposition 21/2, towns whose spending in 1989 is within 0.1 percent of state-mandated spending (levy) limits. Thus voters in these towns must explicitly approve an override allowing spending increases above $2 \frac{1}{2}$ percent per year. Similar to Prediction $2 \mathrm{C}$, we expect that land scarcity (and thereby the extent to which additional spending on schools is capitalized into house values) provides 
stronger incentives to vote for an override. Basic summary statistics support our prediction. Over one-half of constrained towns with little available land pass an override (57 percent) compared with only 35 percent of towns with more potentially developable land.

Table 5 examines determinants of the amount of overrides approved by voters in communities that were near their levy limit in 1989. Column (1) reports results for the base equation with controls for the percentage of developed land in 1984 and other local characteristics for 1990 that may affect demand for education, but without Proposition 21/2 variables. Since these communities are already constrained by Proposition $2 \frac{1}{2}$, there is no reason that Proposition $2 \frac{1}{2} 2$ variables should affect incremental spending. Nonetheless, columns (2) and (3) include early and late 1980s Proposition 21/2 variables, respectively. Finally, column (4) adds endogenous population growth to control for increases in demand. As predicted, the coefficient on percentage developed land is always positive and statistically significant at the 5 percent level (columns (1)-(3)) or at the 10 percent level (column 4). The size of the land scarcity coefficient is quite stable across equations. Few other variables have a statistically significant effect on the cumulative amount of overrides. Given that the impact of overrides is greatest on school spending, it is not surprising that towns with a higher percentage of college-educated adults and a high ratio of school enrollment to total population approve bigger overrides.

\section{Empirical Analysis for the National Sample}

The empirical results in Section 2 demonstrate a consistent relationship between scarcity of developable land and a greater extent of house price capitalization, smaller supply elasticities, and increased school spending. To examine the applicability of these results in a broader setting, we turn to school district level data that covers most areas of the United States. While we lose the nicely identified setting from Massachusetts under Proposition 2⿺辶⿳亠丷厂 , we gain a much broader 
sample that allows us to examine the relationship between land scarcity and school spending in more detail. We provide new results that may help allay concerns that land scarcity might be correlated with other important unobserved amenities or attributes.

\subsection{Capitalization and School Spending}

Previous theoretical research points out that in the presence of house value capitalization, voters take into account preferences of eventual buyers of their house (e.g., Wildasin 1979 and Sonstelie and Portney 1980). If expenditures on durable public goods are not fully capitalized into house prices, communities may underinvest (left of the peak in Figures 2 and 3) because current homeowners do not sufficiently incorporate the utility functions of future residents.

In our context, if home price capitalization is large, some households might vote in favor of spending to improve schools even if they have no children. This is because households could sell their houses in the future to families with children. Of course, the opposite result is possible in communities with perfectly elastic land supply and thereby no capitalization. Investments in durable school facilities will attract other households to the community, converting farmland to residential use, but not raising existing house prices. In this case, households without schoolaged children will pay additional taxes without receiving any benefit, so they have little incentive to support new school spending.

We derive these and other predictions by analyzing voter decisions in a more formal framework. Consider a resident who has the option to vote in favor of or against an investment that aims to provide better local public school services. We assume that the benefit from this investment, $B_{t}$, has a durable component and improves school quality in the future as well as the present period. Even spending on current-use items such as teacher salaries and supplies can have a durable component if such expenditures serve as an indicator of future spending levels 
(e.g., if layoffs are costly). If the majority of voters opt for the investment, property owners will finance the investment with a lump sum tax, $\tau_{t}$, payable now and in future periods. Voters who do not have children in public schools get no current benefit from the investment. Owners of non-residential land, if they live in the town, have similar preferences to voters with no children.

Renters, of course, have smaller incentives than homeowners to vote in favor of an investment that has a durable component. Most renters do not have children and thus receive no benefits from school spending. Renters also do not benefit from possible future increases in house prices. In fact, if rents incorporate any portion of increased taxes, renters will be worse-off as a result of the spending increase. This analysis holds constant the extent to which altruism impacts expenditures. The fact that the US has publicly provided education suggests that altruism plays an important role in determining government expenditures. Yet we also believe that private interests play an additional role in the support for spending-residents who directly benefit from expenditures should be willing to spend more than residents who receive no benefits from those expenditures.

Now consider the determination of house prices. The net benefit of school spending for the marginal homebuyer $j$ may be partially or fully capitalized into house values. If the marginal homebuyer $j$ does not have children in school, the net benefit is $b_{j t}=-\tau_{t}$ and house values may even decline as a result of the investment; otherwise, the net benefit is $b_{j t}=B_{t}-\tau_{t}$ and house values increase to the extent that $B_{t}>\tau_{t}$. The degree of house price capitalization $\theta \in[0,1]$ depends on the land supply elasticity. As above, towns with a more inelastic supply of land for residential construction should have a greater extent of capitalization, $\theta$.

The median voter's payoff is composed of a direct effect (current net benefit of the investment) and an indirect effect (future capitalization effect). The median voter's likelihood of 
voting in favor of the investment depends on: (a) whether the median voter owns a home, (b) the net benefit of the investment, $B_{t}-\tau_{t}$, (c) whether the marginal homebuyer has children, (d) the extent of capitalization, and (e) the median voter's likelihood of moving.

If the median voter is a renter with no children in school, he or she is unlikely to vote for the investment. In this case the extent of capitalization should not affect the probability that the median voter opts for the investment.

Now consider a town where the median voter owns a home. Households with children will vote in favor of the investment if $B_{t}>\tau_{t}$, but such households rarely represent a majority of voters. In such communities, votes by households without children are usually decisive. Equation (5) expresses the payoff to a homeowner without children in the public schools:

$$
P=\left(\sum_{t=1}^{\bar{t}} \frac{-\tau_{t}}{(1+r)^{t}}+\theta \sum_{t=\bar{t}}^{T} \frac{\lambda_{j} B_{t}-\tau_{t}}{(1+r)^{t}}\right),
$$

where $\lambda_{j}=1$ if the future buyer has school-aged children and $\lambda_{j}=0$ otherwise, $r$ is the discount rate, $\bar{t}$ is the expected duration in the property, and $T$ represents the investment duration.

Clearly households with a shorter duration in their house will be more sensitive to the extent of capitalization and the preferences of the future marginal homebuyer. Below, we focus on elderly households who appear to meet two conditions that make them particularly sensitive to house price capitalization: they are likely to have a relatively short expected duration in their house and are unlikely to have school-aged children. Equation (5) implies that elderly homeowners are more likely to support better schools if they live in a place with a greater degree of house price capitalization. We examine these predictions in the empirical work below.

\subsection{Empirical Specification}

Our basic estimating equation for school expenditures per pupil is as follows: 
spending per pupil $=\pi_{0}+\pi_{1}(\%$ developed land $)+\pi_{2}($ local characteristics $)$

$$
\begin{aligned}
& +\pi_{3}(\text { school characteristics })+\pi_{4}(\text { population density }) \\
& +\pi_{5}(\text { state })+\varepsilon
\end{aligned}
$$

Dollar denominated variables such as total school spending per pupil and household income are measured in logs. The equation includes variables that may explain school spending including proxies for costs, educational and demographic characteristics of residents, and state dummy variables. The school district's population density proxies for geographic variation in the cost of providing education that may be correlated with land availability.

Previous research has shown that racial differences and income inequality impact the variability in school spending across communities, including differences in racial composition between the elderly and school-aged children (Poterba 1997) and ethnic fractionalization (Alesina et al. 1999). Following this literature, we include the percentage of non-whites among children aged 5-19 minus the percentage of non-white elderly among total elderly and a measure of the probability that two persons drawn randomly from the population belong to different selfidentified ethnic groups (white, black, American Indian, Asian, Hispanic, and other). We also include the Gini coefficient as a measure of income inequality within each community.

Below we examine whether the percentage developed land in a school district, our proxy for the extent of capitalization, is correlated with higher school spending. While the Massachusetts spending regressions have a quasi-experimental design, the national regressions examine overall per pupil spending levels and assume that most communities in the sample are at or near their desired spending. Given the likelihood that land availability is correlated with other community factors that are unrelated to land supply and might be correlated with school spending, we use theoretical predictions from the model in the previous section that should be specifically driven by a land supply effect, including: 
Prediction 3A: School spending will be positively related to the percentage developed land, our proxy for the extent of house price capitalization.

Prediction 3B: The positive effect of the percentage developed land on school spending should only exist in communities where the median resident is a homeowner.

Prediction 3C: The interaction between percentage developed land and percentage elderly residents should be positive. That is, the elderly should be more willing to support school spending in districts where the extent of capitalization is high, since the elderly have a relatively short time horizon in their property.

Prediction 3D: The positive relationship between percent elderly and percent developed land should be larger for older elderly residents who have a shorter expected duration in their home.

\subsection{Data}

The data used in this section are drawn from the School District Data Book (SDDB) collected by the U.S. Department of Education for the school year 1989/90 and the National Land Cover Data 1992 (NLCD). The SDDB reports total expenditures per pupil, the type of school district, the number of schools within a district, and proxies for school cost (such as the percentage of children below the poverty line, the percentage of children that "speak English not well," or the percentage of children "at risk"13). The SDDB also provides data from the 1990 U.S. Census that is geographically matched to school district boundaries.

The NLCD classifies land use into 21-categories for 48 states (excluding Alaska and Hawaii). The classification is provided as raster data with a spatial resolution of 30 meters derived from satellite photos mostly acquired from 1991 to 1993. The Wharton GIS Lab

\footnotetext{
${ }^{13}$ A child, 6 to 19 years of age, is defined "at risk" if the child is not a high school graduate and lives with a mother who is not a high school graduate or is divorced or separated, and whose income is below the 1989 poverty level.
} 
geographically matched the raster data to the school district level boundaries. 'Percentage developed land' is calculated as the ratio of developed residential land to total developable land. ${ }^{14}$

We exclude data on school districts from states with full school finance equalization (California, Hawaii, and New Mexico) as our theory only applies to school districts with at least partial local control over school spending. We also exclude school districts with missing data, with implausibly low or high total expenditures per pupil, and the five percent of school districts with enrollments of less than 70 students as their per-pupil costs are likely to be quite high. Table 6 reports summary statistics for our final sample of 11,565 school districts.

\subsection{Results}

To begin, we examine Prediction 3A; school districts with less available land for new development will have greater per-pupil expenditures. Table 7 reports estimates for per-pupil school spending as in equation (6). Column (1) shows the results for the base equation that includes the percentage developed land as a proxy for land supply inelasticity. The percentage developed land is strongly and positively related to school spending, even when controlling for household income, the educational and demographic background of residents, cost variables, school agency specific characteristics, ethnic factors, and population density.

The coefficient on percentage developed land is both statistically significant (p-value of 99 percent) and economically meaningful. Table 9 presents quantitative effects for two hypothetical school districts: a less developed school district at the $75^{\text {th }}$ percentile (with $6.6 \%$ of all developable non-industrial land used for residential purposes) and a more developed school district at the $95^{\text {th }}$ percentile (with $68.1 \%$ of developable non-industrial land used for residential purposes). The coefficients suggest that the school district in a location with more developed

\footnotetext{
${ }^{14}$ Land is considered non-developable if it is classified as industrial, open water, perennial ice, barren, or wetland. Our results are essentially unchanged if we drop industrial land from the list of non-developable uses.
} 
land spends $10.7 \%$ more on schools than the district in a less developed location. This represents an additional $\$ 549$ per pupil relative to mean per-pupil spending of $\$ 5,131$.

Most other control variables have the expected effect on school spending and are reported in the Appendix Table. Schools spend more money in districts with a higher percentage of children below the poverty line or who speak English "not well". Economies of scale appear important. School districts with more schools spend less per-pupil (at a decreasing rate), as do districts in more densely populated locations. School spending increases with the percentage of residents with a college education and with the median household income. However, ethnic polarization has no statistically significant effect on school spending. ${ }^{15}$

The results in column (2) support Prediction 3B; the relationship between percentage developed land and school spending is closely tied to homeownership. When the homeownership dummy variable (which equals 1 if the district's homeownership rate exceeds fifty percent) is interacted with the percent developed land, the coefficient on the interaction is positive and significant at the 1 percent level, while the coefficient on percent developed land is small and no longer statistically significant. These results suggest that the positive relationship between percentage developed land and spending only exists in communities where the median resident is a homeowner. Note that the coefficient on the homeownership dummy itself is negative suggesting that homeowners per se are less willing to support school spending compared to renters if such increases have no positive impact on property values. Table 9 (row 3) indicates that the positive effect of land scarcity on school spending (+10.7 percent) is almost exclusively

\footnotetext{
${ }^{15}$ The coefficient on ethnic polarization is not inconsistent with Alesina et al. (1999), who find that ethnic polarization is negatively related to the school share of total spending at the city level, but positively related to overall spending. Their model has an ambiguous prediction about the impact of ethnic polarization on overall school spending.
} 
confined to locations with homeowner-majorities, which is in line with the predictions of our model in Section 3.1.

Columns (3) to (5) show that the percentage of elderly residents is positively related to additional school spending only in school districts with a greater percent developed land. We interact percent elderly with percent developed land and run separate regressions that define elderly residents as those aged 65 and above, 75 and above, and 85 and above. Predictions 3C and $3 \mathrm{D}$ suggest that the interactions will be positive and increase in magnitude for the older elderly residents who have progressively shorter expected durations in their property. In all three columns, the interaction between percent elderly and percentage developed land is positive and, as predicted, the size of the coefficients on these interactions rises with age. Two of the three interaction effects are statistically significant with p-values exceeding 95 percent. The interaction effect for elderly residents aged 75 and above has a p-value of 87 percent. The direct effect of percent elderly is either insignificant or negative. Table 9 shows that a one standard deviation increase in the percent elderly results in higher spending of between 0.8 and 2.7 percent in districts with more developed land relative to districts with less developed land.

Next we add location fixed effects, confining our analysis to cross-sectional variation within specific location types. The data allow us to categorize districts based on their location in central cities of large MSAs (population over 1 million in MSA), in suburbs of large MSAs, in central cities of medium-sized MSAs (MSA population between 250,000 and 1 million), in suburbs of medium-sized MSAs, in central cities of small MSAs (MSA population below 250,000), in suburbs of small MSAs, and in non-MSA locations.

The results in Table 8 with the new location controls confirm our earlier findings. Table 9 reports quantitative effects. For example, the coefficient in column (1) suggests that the more developed locations spend about 9.2 percent (or $\$ 472$ per pupil) more on schools. This compares 
to 10.7 percent (or \$549) in the base specification without location type controls. The results in column (2) are the same as our earlier finding that the relationship between percentage developed land and school spending is confined to districts with homeowner majorities. Finally, the interactions between percent elderly and percentage developed land are larger in magnitude than those in Table 7 and are statistically significant with p-values exceeding 95 percent for all three age categories.

To further test the validity of our results, we estimate a number of additional specifications. The results of these additional specification tests, which were reported in previous versions of the paper, confirm our main findings and are available from the authors upon request.

For example, we estimate our base regressions without any controls for crime. Unfortunately, crime data is incomplete or missing for many districts in our sample. Some readers have suggested that the locations with a higher percentage developed land might also have a higher crime rate, biasing our analysis. To examine this hypothesis, we obtain crime rates at the zip code level in as many jurisdictions as possible from the FBI. ${ }^{16}$ Crime data is considerably more problematic than other variables because not all jurisdictions report crime data and the geographical make-up of jurisdictions differs between school districts and police forces. For example, some communities have local schools, but their crime rates are only reported at the county level. Given the difficulties of using disaggregated crime statistics that are unlikely to be accurate for particular locations, we primarily examine school districts where the crime data are reported at the city level or below. ${ }^{17}$ This exclusion decreases our sample by one-third, leaving

\footnotetext{
${ }^{16}$ The crime data come from U.S. Dept. of Justice, Federal Bureau of Investigation. Uniform Crime Reporting Program Data: United States_-Offenses Known and Clearances by Arrest, 1990, compiled by the U.S. Dept. of Justice, Federal Bureau of Investigation. ICPSR ed. Ann Arbor, MI: Inter-university Consortium for Political and Social Research (producer and distributor), 1997. We also used zip code information from ESRI Inc. and Geographic Data Technology, Inc. to help match the crime data with the school agency information.

${ }^{17}$ All of the results with crime rates are similar if we apply county-level crime rates to individual agencies, although we believe this approach to be less accurate.
} 
7,979 remaining school districts. The greatest loss of observations is for rural places without their own police forces.

The inclusion of crime rate variables has little effect on the empirical results reported in Tables 7 and 8 . The coefficient on percentage developed land is highly statistically significant but slightly smaller than in Table 7 if we estimate our base specification with the sample of locations with non-missing crime data. When we add the murder rate and the murder rate interacted with the homeownership rate or the percent elderly, the coefficients on percentage developed land and its interaction terms are either unchanged or are slightly larger in magnitude. The coefficient on the murder rate itself is positive and statistically significant at the 90 percent level; suggesting that locations with higher crime rates spend more on schools. The coefficients on the interaction between elderly and murder rate or homeownership and murder rate are negative and marginally statistically significant. These findings are unchanged if we use all crimes or crimes committed by juveniles instead of the murder rate.

We consider three additional specification checks. First, we examine the data in California and New Mexico, where spending is determined at the state level. The predictions from Section 3.1 should only hold for districts that have at least partial control over school spending. When we run the regressions in Tables 7 and 8 for these two states, the coefficients on developable land and its interaction terms are statistically insignificant and economically small. We also estimate our equations omitting population density, which captures the cost of providing education but may also be correlated with percentage developed land. The results are not appreciably different and, in fact, statistical significance levels on the interaction terms improve slightly. Finally, our main results remain qualitatively unchanged and significance levels are somewhat improved when we add state and federal revenue per pupil to the base equation. It is worth noting that the 
results imply that local districts increase total spending by only about 2.5 percent of the revenue received from state and federal sources.

\section{Conclusion}

This paper argues that the extent of house price capitalization within a school district is an important factor in determining spending, encouraging homeowners to support additional school spending even if they have no school-aged children. We argue that house price capitalization is highest in developed areas where there is little available land for new construction, while capitalization is lower in locations where land is more readily available. Hence, localities with little available land should spend more on schools, all else equal. We expect these effects to be most pronounced when the median voter is a homeowner and in places where elderly live, as the elderly typically own homes and have a relatively short expected duration in their house.

We examine these theoretical predictions using two alternative data sources. First, we take advantage of a unique shock to local spending, Proposition 21/2 in Massachusetts. We find that fiscal variables and amenities are capitalized to a much greater extent in towns with little available land and that these locations also have a lower elasticity of land supply. Communities with little remaining developable land spend more on schools and their voters are more likely to pass spending overrides in order to undertake new spending.

Next we examine school spending from 1990 in 46 states and show that per pupil spending is higher in school districts with little available developable land. The estimates are quite large. For example, a community with 68.1 percent developed land spends $\$ 549$ (10.7 percent) more per pupil than a town with 6.6 percent developed land. Consistent with theory, the estimated positive relationship between percent developed land and spending is confined to school districts with homeownership rates above fifty percent. Finally, we demonstrate that elderly voters are not 
necessarily averse to public school spending. A higher percent of elderly voters in more developed locations is correlated with increased spending on schools, but more elderly residents in undeveloped (rural) areas are associated with unchanged or even lower school spending levels. The correlation between spending and the interaction of percent elderly and percent developed land becomes larger when one examines older elderly citizens who have a shorter expected duration in their house.

These findings raise questions about the future of school spending in the U.S. Poterba (1998) suggests that the coming increase in percentage of elderly voters might lead to cuts in real education spending, although he speculates that house price capitalization might serve as a counterweight. Our results suggest that an increasing share of elderly voters does not necessarily portend lower school spending in more heavily developed places. However, projecting these results into the future relies heavily on the assumption that the marginal homebuyer will continue to value public schools in most communities.

More generally, these results support models in which house prices encourage the efficient provision of public services. In this regard, the fact that voters care about the preferences of future generations of (marginal) homebuyers provides positive incentives to provide a variety of services that may be consumed by only a minority of current residents. It also discourages communities from financing their services by imposing burdens on future generations of residents or home buyers. 


\section{References}

Alesina, A., R. Baqir, and W. Easterly. 1999. Public Goods and Ethnic Divisions. Quarterly Journal of Economics 114:1243-84.

Barrow, L. and C. E. Rouse. 2004. Using Market Valuation to Assess Public School Spending. Journal of Public Economics 88:1747-1769.

Bergstrom, T. C., D. L. Rubinfeld, and P. Shapiro. 1982. Micro-Based Estimates of Demand Functions for Local School Expenditures. Econometrica 50:1183-1205.

Black, S. E. 1999. Do Better Schools Matter? Parental Valuation of Elementary Education. Quarterly Journal of Economics 114:577-600.

Blomquist, G., M. C. Berger, and J. P. Hoehn. 1988. New Estimates of Quality of Life in Urban Areas. American Economic Review 78:89-107.

Bogart, W. T. and B. A. Cromwell. 1997. How Much More Is a Good School District Worth? National Tax Journal 50:215-232. . 2000. How Much Is a Neighborhood School Worth? Journal of Urban Economics 47:280305.

Bradbury, K. L., C. J. Mayer, and K. E. Case. 2001. Property Tax Limits, Local Fiscal Behavior, and Property Values: Evidence from Massachusetts Under Proposition 21/2. Journal of Public Economics 80:287-311.

Brasington, D. M. 2002. Edge Versus Center: Finding Common Ground in the Capitalization Debate. Journal of Urban Economics 52: 524-41.

Bruce, D. and D. Holtz-Eakin. 1999. Fundamental Tax Reform and Residential Housing. Journal of Housing Economics 8:249-271.

Brueckner, J. K. 1982. A Test for Allocative Efficiency in the Local Public Sector. Journal of Public Economics 19:311-31.

Brueckner, J. K. and M.-S. Joo. 1991. Voting with Capitalization. Regional Science and Urban Economics 21:453-467.

Bui, L. and C. J. Mayer. 2003. Regulation and Capitalization of Environmental Amenities:

Evidence from the Toxics Release Inventory in Massachusetts. Review of Economics and Statistic 85:693-708.

Capozza, D. R. and R. W. Helsley. 1989. The Fundamentals of Land Prices and Urban Growth. Journal of Urban Economics 26: 295-306. 
1990. The Stochastic City. Journal of Urban Economics 28: 187-203.

Capozza, D. R., R. K. Green, and P. H. Hendershott. 1996. Taxes, Mortgage Borrowing, and Residential Land Prices. In Economic Effects of Fundamental Tax Reform, edited by H. J. Aaron and W. G. Gale. Washington, D.C.: Brookings Institution Press.

Case, K. E. and C. J. Mayer. 1996. Housing Price Dynamics within a Metropolitan Area. Regional Science and Urban Economics 26:387-407.

Cheshire, P. and S. Sheppard. 2004. Capitalising the Value of Free Schools: The Impact of Supply Characteristics and Uncertainty. Economic Journal 114:397-424.

Conley, J. P. and A. Rangel. 2001. Intergenerational Fiscal Constitutions: How to Protect Future Generations Using Land Taxes and Federalism. NBER Working Paper No. 8394, July.

Cutler, D. M., D. W. Elmendorf, and R. J. Zeckhauser 1993. Demographic Characteristics and the Public Bundle. Public Finance 48:178-98.

Dee, T. S. 2000. The Capitalization of Education Finance Reforms. Journal of Law and Economics 43:185-214.

Edelson, N. M. 1976. Voting Equilibria with Market-based Assessments. Journal of Public Economics 5:269-284.

Fischel, W. A. 1985. The Economics of Zoning Laws. Baltimore: Johns Hopkins University Press.

2001. Homevoters, Municipal Corporate Governance, and the Benefit View of the Property Tax. National Tax Journal 54:157-173.

Glaeser, E. 1996. The Incentive Effects of Property Taxes on Local Governments. Public Choice 89:93-111.

Goldin, C. and L. Katz. 1997. Why the United States Led in Education: Lessons From Secondary School Expansion, 1910 to 1940. NBER Working Paper No. 6144, August. . 1999. Human Capital and Social Capital: The Rise of Secondary Schooling in America, 1910 to 1940. Journal of Interdisciplinary History 29:683-723.

Gyourko, J., M. Kahn, and J. Tracy. 1999. Quality of Life and Environmental Comparisons. In Handbook of Regional and Urban Economics, edited by P. Cheshire and E. S. Mills. New York: North-Holland.

Gyourko, J. and J. Tracy. 1991. The Structure of Local Public Finance and the Quality of Life. Journal of Political Economy 99:774-806. 
Gyourko, J. and R. Voith. 2000. The Price Elasticity of the Demand for Residential Land. The Wharton School Working Paper, February.

Hamilton, B. W. 1976. Capitalization of Intrajurisdictional Differences in Local Tax Prices. American Economic Review 66:743-753.

Harris, A. R., W. N. Evans, and R. M. Schwab. 2001. Education Spending in an Aging America. Journal of Public Economics 81:449-472.

Harter-Dreiman, M. 2004. Drawing Inferences about Housing Supply Elasticity from House Price Responses to Income Shocks. Journal of Urban Economics 55:316-337.

Haurin, D. R. and D. Brasington. 1996. The Impact of School Quality on Real House Prices: Interjurisdictional Effects. Journal of Housing Economics 5:351-368.

Hoxby, C. M. 1998. How Much Does School Spending Depend on Family Income? The Historical Origins of the Current School Finance Dilemma. American Economic Review 88: 309-14.

Hwang, M. and J. Quigley. 2004. Economic Fundamentals in Local Housing Markets: Evidence from U.S. Metropolitan Regions. University of California Berkeley mimeo.

Inman, R. P. 1978. Testing Political Economy’s ‘As If’ Proposition: Is the Median Voter Really Decisive? Public Choice 33(4): 45-65.

Malpezzi, S. 1996. Housing Prices, Externalities, and Regulation in U.S. Metropolitan Areas, Journal of Housing Research 7:209-241.

Man, J. Y., and M. E. Bell. 1996. The Impact of Local Sales Tax on the Value of OwnerOccupied Housing. Journal of Urban Economics 39:114-131.

Mayer, C. J., and C. T. Somerville. 2000. Land Use Regulation and New Construction. Regional Science and Urban Economics 30:639-62.

Novy-Marx, R. 2004. An Equilibrium Model of Investment Under Uncertainty. University of Chicago Graduate School of Business mimeo.

Oates, W. E. and R. Schwab. 1988. Economic Competition Among Jurisdictions: Efficiency Enhancing or Distortion Inducing? Journal of Public Economics 35:333-354. . 1996. The Theory of Regulatory Federalism: The Case of Environmental Management. In The Economics of Environmental Regulation, edited by W. E. Oates. Aldershot, UK: Edward Elgar. 
Palmon, O. and B. A. Smith. 1998a. New Evidence on Property Tax Capitalization. Journal of Political Economy 106:1099-1111.

1998b. A New Approach for Identifying the Parameters of a Tax Capitalization Model. Journal of Urban Economics 44:299-316.

Pogodzinski, J. M. and T. R. Sass. 1994. The Theory and Estimation of Endogenous Zoning. Regional Science and Urban Economics 24:601-630.

Poterba, J. 1997. Demographic Structure and the Political Economy of Public Education. Journal of Public Policy and Management 16:48-66. 1998. Demographic Change, Intergenerational Linkages, and Public Education. American Economic Review 88:315-320.

Rudel, T. K. 1989. Situations and Strategies in American Land-Use Planning. Cambridge, England: Cambridge University Press.

Smith, V. K. and J.-C. Huang. 1995. Can Markets Value Air Quality? A Meta-Analysis of Hedonic Property Value Models. Journal of Political Economy 103:209-227.

Sonstelie, J. C. and P. R. Portney. 1978. Profit Maximizing Communities and the Theory of Local Public Expenditures. Journal of Urban Economics 5:263-277. . 1980. Take the Money and Run: A Theory of Voting in Local Referenda. Journal of Urban Economics 8:187-195.

Stull, W. J., and J. C. Stull. 1991. Capitalization of Local Income Taxes. Journal of Urban Economics 29:182-190.

Tiebout, Charles M. 1956. A Pure Theory of Local Expenditures. Journal of Political Economy, 64(5): 416-24.

Weimer, D. L. and M. J. Wolkoff. 2001. School Performance and Housing Values: Using Noncontiguous District and Incorporation Boundaries to Identify School Effects. National Tax Journal 54:231-53.

Wildasin, D. E. 1979. Local Public Goods, Property Values, and Local Public Choice. Journal of Urban Economics 6, 521-534.

Wyckoff, P. G. 1995. Capitalization, Equalization, and Intergovernmental Aid. Public Finance Quarterly 23:484-508. 


\title{
Summary Statistics and Regression Tables
}

\author{
Table 1
}

Variable List and Means

$\mathrm{N}=208$

\begin{tabular}{|c|c|c|c|c|}
\hline Variable & Mean & $\begin{array}{c}\text { Standard } \\
\text { Deviation }\end{array}$ & Minimum & Maximum \\
\hline \multicolumn{5}{|l|}{ Endogenous Variables: } \\
\hline Percent change in house prices, FY1990-94 & -.077 & .057 & -.208 & .071 \\
\hline Percent change in school spending, FY1990-94 & .15 & .09 & -.15 & .54 \\
\hline Percent change in non-school spending, FY1990-94 & .083 & .158 & -.323 & .680 \\
\hline Single family permits, $1990-94$, per 1990 housing unit & .046 & .038 & .001 & .230 \\
\hline \multicolumn{5}{|l|}{ Fiscal Variables: } \\
\hline Effective property tax rate, FY1980 & .031 & .009 & .012 & .086 \\
\hline Dummy, one year of initial levy reductions, FY1982 & .46 & .50 & 0 & 1 \\
\hline Dummy, two years of initial levy reductions, FY1982-83 & .12 & .32 & 0 & 1 \\
\hline Dummy, three years of initial levy reductions, FY1982-84 & .034 & .181 & 0 & 1 \\
\hline Excess capacity as percentage of levy limit, FY1989 & .018 & .036 & $1.1 \mathrm{e}-7$ & .20 \\
\hline Dummy variable, at levy limit and no overrides, FY1989* & .44 & .50 & 0 & 1 \\
\hline Dummy variable, passed override(s) prior to FY1990 & .11 & .31 & 0 & 1 \\
\hline Dummy variable, "unconstrained" in FY1989* & .46 & .50 & 0 & 1 \\
\hline Equalized property value per capita, 1980 (000) & 16.4 & 6.2 & 6.3 & 44.1 \\
\hline Nonresidential share of property value, FY1980 & .19 & .09 & .04 & .60 \\
\hline Percentage of revenue from state aid, FY 1984 & .26 & .10 & .05 & .52 \\
\hline Percentage of revenue from state aid, FY1981 & .19 & .08 & .05 & .43 \\
\hline Percentage increase in state aid, FY1981-84 & .43 & .31 & -.44 & 3.38 \\
\hline \multicolumn{5}{|l|}{ Community Characteristics: } \\
\hline School test scores, $1990^{*}$ & 2690 & 168 & 2160 & 3080 \\
\hline Fraction of 1980 population under age 5 & .062 & .013 & .032 & .11 \\
\hline Fraction of 1990 population over age 65 & .13 & .034 & .027 & .22 \\
\hline Dummy variable, in Boston metro area (PMSA) & .45 & .50 & 0 & 1 \\
\hline Dummy variable, in Boston suburban ring* & .19 & .40 & 0 & 1 \\
\hline Fraction developed land in community, $1984 *$ & .88 & .054 & .74 & .97 \\
\hline Single family permits per 1990 housing unit, 1989 & .008 & .007 & .000 & .038 \\
\hline Enrollment/population ratio, 1981 & .20 & .04 & .08 & .42 \\
\hline Median family income, $1980(000)$ & 21.0 & 5.6 & 11.5 & 47.6 \\
\hline Dummy variable, member of regional district & .26 & .44 & 0 & 1 \\
\hline Dummy variable, member of regional high school & .19 & .39 & 0 & 1 \\
\hline Percent of adult residents with college education, 1980 & .20 & .12 & .05 & .60 \\
\hline
\end{tabular}

Notes, marked with asterisks:

"At levy limit" is defined as levy within 0.1 percent of levy limit.

"Unconstrained" communities are not at levy limit in FY1989 and have passed no overrides prior to FY1990.

School test scores is combined math and reading MEAP test score for 8th graders in 1990.

Boston suburban ring is defined as within MSA but outside PMSA.

Developable land is defined as open land (including farmland) or public land.

Sources: Massachusetts Department of Education; Massachusetts Department of Revenue, Division of Local Services, Municipal Data Bank; U.S. Department of Commerce, Bureau of the Census. 


\section{Table 2}

\section{House Price Regression Results Using Land Availability as Proxy for the Elasticity of Supply of Open Land for New Residential Construction Dependent Variable: Percent Change in House Prices, Fiscal Years 1990-1994}

Specification

Explanatory Variable
Sample divided by percentage of open and public (developable) land

Less More

Developable Land

(1)

Developable Land

(2)

Single family permits, 1990-1994, per 1990 housing units
$-.70 * *$

$(.22)$

$.33 * *$

.075

(.086)

$.14 * *$

(.029)

$.097 * *$

(.012)

$.11 * *$

$-.55 * *$

(.077)
$-.11$

(.061)

$.11 * *$

(.031)

$.074 * *$

$.036 * *$

(.0091)

$-.43 * *$

(.078)
Number of observations

104

104 


\section{Table 3}

\section{Land Supply Elasticity Regression Results}

Dependent Variable: Single Family Permits, 1990-1994, per 1990 Housing Units

Sample divided by percentage of open and public (undeveloped) land in each community

\begin{tabular}{|c|c|c|c|c|c|}
\hline \multirow{2}{*}{$\begin{array}{l}\text { Specification } \\
\text { Explanatory Variable }\end{array}$} & \multicolumn{2}{|c|}{$\begin{array}{c}\text { Base set of instruments } \\
\text { (without lagged supply as } \\
\text { exogenous variable) }\end{array}$} & \multicolumn{3}{|c|}{$\begin{array}{l}\text { Base set of instruments } \\
\text { (with lagged supply as } \\
\text { exogenous variable) }\end{array}$} \\
\hline & $\begin{array}{l}\text { Less } \\
\text { Developable } \\
\text { Land } \\
\text { (1a) }\end{array}$ & $\begin{array}{c}\text { More } \\
\text { Developable } \\
\text { Land } \\
\text { (1b) }\end{array}$ & $\begin{array}{l}\text { Less } \\
\text { Developable } \\
\text { Land } \\
\text { (2a) }\end{array}$ & $\begin{array}{l}\text { More } \\
\text { Developabl } \\
\text { Land } \\
\text { (2b) }\end{array}$ & ble \\
\hline $\begin{array}{l}\text { Percentage change in house prices, } \\
1990-1994\end{array}$ & $\begin{array}{r}.014 \\
(.055)\end{array}$ & $\begin{array}{l}.16 * * \\
(.079)\end{array}$ & $\begin{array}{l}.13 \\
(.038)\end{array}$ & $\begin{array}{r}.18 *: \\
(.046)\end{array}$ & $* *$ \\
\hline $\begin{array}{l}\text { Single family permits, } 1989, \\
\text { per } 1990 \text { housing units }\end{array}$ & & & $\begin{array}{r}4.9 * * \\
(.44)\end{array}$ & $\begin{array}{r}3.6 *: \\
(.43)\end{array}$ & ** \\
\hline Constant & $\begin{array}{l}.043 * * \\
(.0056)\end{array}$ & $\begin{array}{r}.064 * * \\
(.0086)\end{array}$ & $\begin{array}{r}.017 * * \\
(.0050)\end{array}$ & $\begin{array}{l}.032 \\
(.0061)\end{array}$ & \\
\hline Number of observations & 104 & 104 & 104 & 104 & \\
\hline
\end{tabular}

Notes: Numbers in parentheses are robust standard errors. * Significantly different from zero with 90 percent confidence. ** Significantly different from zero with 95 percent confidence. Bold variable is endogenous. The instruments are all of the exogenous variables in the demand equation in Table 2 (i.e., combined math and reading MEAP test scores, dummy variable in Boston metro area, and dummy variable in Boston suburban ring), the percentage of population less than 5 years old in 1990 plus the following spending shifter-instruments from the demand equation in Table 2: effective tax rate in 1980, equalized property value per capita 1980, enrollment per population 1981, median family income 1980, percentage of revenue from state aid 1981, non residential share of property value 1980, percentage of adults with a college degree 1980, percentage increase in state aid 1981-1984, dummies for regional school district or high school, dummy variables for the number of years required to reduce spending due to Proposition $2 \frac{1}{2}$. 


\section{Table 4}

Spending Regression Results for Massachusetts

Dependent Variable: Percent Change in School or Non-School Spending, Fiscal Years 1990-94

\begin{tabular}{|c|c|c|c|c|c|c|c|c|}
\hline \multirow{2}{*}{$\begin{array}{l}\text { Explanatory Variable } \\
\text { Percentage of developed land in } 1984\end{array}$} & \multicolumn{2}{|c|}{$\begin{array}{c}\text { School } \\
\text { Spending } \\
(1) \\
\end{array}$} & \multicolumn{2}{|c|}{$\begin{array}{l}\text { Non-school } \\
\text { Spending } \\
(2) \\
\end{array}$} & \multicolumn{2}{|c|}{$\begin{array}{c}\text { School } \\
\text { Spending } \\
(3) \\
\end{array}$} & \multicolumn{2}{|c|}{$\begin{array}{l}\text { Non-school } \\
\text { Spending } \\
\text { (4) }\end{array}$} \\
\hline & .24 & $* *$ & .24 & & .25 & $* *$ & .29 & \\
\hline & $(.12)$ & & $(.18)$ & & $(.12)$ & & $(.20)$ & \\
\hline Percent change in number of students, 1990-94 & .74 & $* *$ & & & .77 & $* *$ & & \\
\hline & $(.17)$ & & & & $(.16)$ & & & \\
\hline Percent change in population, 1990-94 & & & $\begin{array}{r}1.2 \\
(.61)\end{array}$ & $* *$ & & & $\begin{array}{r}1.1 \\
(.63)\end{array}$ & $*$ \\
\hline Equalized property value per capita, FY1990 $\left(\times 10^{-7}\right)$ & 7.4 & & 4.5 & & 8.2 & & 10.0 & \\
\hline & $(5.0)$ & & $(7.4)$ & & (5.6) & & $(7.5)$ & \\
\hline Ratio, enrollment to population, FY1990 & $\begin{array}{r}.59 \\
(.29)\end{array}$ & $* *$ & $\begin{array}{r}-.42 \\
(.44)\end{array}$ & & $\begin{array}{r}.70 \\
(.28)\end{array}$ & $* *$ & $\begin{array}{r}-.20 \\
(.45)\end{array}$ & \\
\hline Median family income (in '000), 1990 & $\begin{array}{l}-.0029 \\
(.0012)\end{array}$ & $* *$ & $\begin{array}{r}-.00033 \\
(.0020)\end{array}$ & & $\begin{array}{r}-.0034 \\
(.0013)\end{array}$ & $* *$ & $\begin{array}{r}-.00010 \\
(.0020)\end{array}$ & \\
\hline Percentage of revenue from state aid, FY1984 & $\begin{array}{r}.26 \\
(.10)\end{array}$ & $* *$ & $\begin{array}{l}.025 \\
(.22)\end{array}$ & & $\begin{array}{r}.26 \\
(.099)\end{array}$ & $* *$ & $\begin{array}{l}-.13 \\
(.20)\end{array}$ & \\
\hline Percentage increase in state aid, FY1981-84 & $\begin{array}{r}-.0094 \\
(.15)\end{array}$ & & $\begin{array}{r}.033 \\
(.029)\end{array}$ & & $\begin{array}{r}-.00015 \\
(.013)\end{array}$ & & $\begin{array}{r}.055 \\
(.030)\end{array}$ & $*$ \\
\hline Nonresidential share of property value, FY1990 & $\begin{array}{r}.015 \\
(.076)\end{array}$ & & $\begin{array}{r}-.0093 \\
(.12)\end{array}$ & & $\begin{array}{l}-.025 \\
(.079)\end{array}$ & & $\begin{array}{r}-.057 \\
(.13)\end{array}$ & \\
\hline Dummy variable: member of regional school district & $\begin{array}{r}.053 \\
(.027)\end{array}$ & $* *$ & $\begin{array}{r}-.027 \\
(.073)\end{array}$ & & $\begin{array}{r}.053 \\
(.026)\end{array}$ & $* *$ & $\begin{array}{l}-.058 \\
(.066)\end{array}$ & \\
\hline Dummy variable: member of regional high school & $\begin{array}{l}-.019 \\
(.025)\end{array}$ & & $\begin{array}{l}-.014 \\
(.069)\end{array}$ & & $\begin{array}{l}-.021 \\
(.025)\end{array}$ & & $\begin{array}{c}.026 \\
(.064)\end{array}$ & \\
\hline $\begin{array}{l}\text { Percent of adult residents with college education, } \\
1990\end{array}$ & $\begin{array}{r}.18 \\
(.097)\end{array}$ & $*$ & $\begin{array}{l}-.12 \\
(.17)\end{array}$ & & $\begin{array}{r}.18 \\
(.10)\end{array}$ & $*$ & $\begin{array}{r}-.058 \\
(.19)\end{array}$ & \\
\hline Effective property tax rate, FY1980 & $\begin{array}{r}1.7 \\
(1.1)\end{array}$ & & $\begin{array}{r}-1.4 \\
(2.2)\end{array}$ & & $\begin{array}{r}2.4 \\
(1.1)\end{array}$ & $* *$ & $\begin{array}{l}-.32 \\
(2.0)\end{array}$ & \\
\hline $\begin{array}{l}\text { Dummy variable, required one year of initial levy } \\
\text { reductions, FY1982 }\end{array}$ & $\begin{array}{r}-.013 \\
(.014)\end{array}$ & & $\begin{array}{r}.022 \\
(.030)\end{array}$ & & $\begin{aligned}-.021 \\
(.014)\end{aligned}$ & & $\begin{array}{r}.012 \\
(.031)\end{array}$ & \\
\hline $\begin{array}{l}\text { Dummy variable, required two years of initial levy } \\
\text { reductions, FY1982-83 }\end{array}$ & $\begin{aligned}-.088 \\
(.028)\end{aligned}$ & $* *$ & $\begin{array}{r}-.015 \\
(.048)\end{array}$ & & $\begin{array}{r}-.094 \\
(.030)\end{array}$ & $* *$ & $\begin{array}{r}-.013 \\
(.046)\end{array}$ & \\
\hline $\begin{array}{l}\text { Dummy variable, required three years of initial levy } \\
\text { reductions, FY1982-84 }\end{array}$ & $\begin{array}{r}-.16 \\
(.051)\end{array}$ & $* *$ & $\begin{array}{r}.051 \\
(.072)\end{array}$ & & $\begin{array}{r}-.17 \\
(.049)\end{array}$ & $* *$ & $\begin{array}{r}.042 \\
(.073)\end{array}$ & \\
\hline $\begin{array}{l}\text { Excess spending per pupil (required }>\text { actual } \\
\text { spending), FY1994 }\end{array}$ & $\begin{array}{l}.0070 \\
(.083)\end{array}$ & & $\begin{array}{r}-.34 \\
(.17)\end{array}$ & $* *$ & & & & \\
\hline $\begin{array}{l}\text { Excess capacity as a percentage of levy limit, } \\
\text { FY1989 }\end{array}$ & $\begin{array}{r}.43 \\
(.30)\end{array}$ & & $\begin{array}{l}-.11 \\
(.32)\end{array}$ & & & & & \\
\hline $\begin{array}{l}\text { Dummy variable, at levy limit and no overrides, } \\
\text { FY1989 }\end{array}$ & $\begin{array}{r}.045 \\
(.017)\end{array}$ & $* *$ & $\begin{array}{r}.046 \\
(.027)\end{array}$ & $*$ & & & & \\
\hline Dummy variable, passed override(s) prior to FY1990 & $\begin{array}{r}.058 \\
(.020)\end{array}$ & $* *$ & $\begin{array}{r}.14 \\
(.034)\end{array}$ & $* *$ & & & & \\
\hline Constant & $\begin{array}{r}-.33 \\
(.13)\end{array}$ & $* *$ & $\begin{array}{r}-.055 \\
(.20)\end{array}$ & & $\begin{array}{l}-.31 \\
(.13)\end{array}$ & $* *$ & $\begin{array}{c}-.18 \\
(.21)\end{array}$ & \\
\hline Adjusted R-squared & .15 & & .22 & & .081 & & .12 & \\
\hline Number of observations & 208 & & 208 & & 208 & & 208 & \\
\hline
\end{tabular}

Notes: Numbers in parentheses are robust standard errors. * Significantly different from zero with 90 percent confidence. ** Significantly different from zero with 95 percent confidence. Bold variables are endogenous. Spending equations (1) and (2) include fiscal variables from the early 1980s, Proposition 21/2 variables from 1989, and the excess spending per pupil in 1994 (required>actual spending). Spending equations (3) and (4) include fiscal variables from 1990 and early Proposition 21/2 variables. Instruments include the demand shifters from the demand equation in Table 2 (i.e., the combined math and reading MEAP test scores and dummy variables for the Boston metro area and the suburban ring) plus the quantity and pupil shifters (i.e., the lagged permits in 1989 per 1990 housing units and the percentage of population less than 5 years old in 1990). 
Table 5

Override Regression Results Including Percentage of Developed Land As Independent Variable

Dependent Variable: Cumulative Amount of Overrides Passed in a Community per Capita, FY 1990-1994

\begin{tabular}{|c|c|c|c|c|c|c|c|c|}
\hline \multirow{2}{*}{$\begin{array}{l}\text { Explanatory Variable } \\
\text { Percent change in population, 1990-94 }\end{array}$} & $\begin{array}{r}\text { OLS } \\
\text { Base Equ } \\
\text { (1) }\end{array}$ & ation & \multicolumn{2}{|c|}{$\begin{array}{c}\text { OLS } \\
\text { Base Equation } \\
\text { Plus Early } 80 \mathrm{~s} \\
\text { Prop. 21/2 Var. } \\
\text { (2) }\end{array}$} & \multicolumn{2}{|c|}{$\begin{array}{c}\text { OLS } \\
\text { Base Equation } \\
\text { Plus Late } 80 \mathrm{~s} \\
\text { Prop. 21/2 Var. } \\
(3) \\
\end{array}$} & \multicolumn{2}{|c|}{$\begin{array}{c}\text { 2SLS } \\
\text { Endogenous } \\
\text { Population } \\
\text { Change } \\
(4) \\
\end{array}$} \\
\hline & & & & & & & $\begin{array}{r}-296.3 \\
(144.0)\end{array}$ & *** \\
\hline Percentage of developed land in 1984 & $\begin{array}{l}106.1 \\
(47.6)\end{array}$ & $* *$ & $\begin{array}{l}117.5 \\
(52.0)\end{array}$ & $* *$ & $\begin{array}{l}118.0 \\
(52.8)\end{array}$ & $* *$ & $\begin{array}{r}75.2 \\
(46.5)\end{array}$ & $*$ \\
\hline Equalized property value per capita, FY1990 $\left(\times 10^{-3}\right)$ & $\begin{array}{r}.45 \\
(.32)\end{array}$ & & $\begin{array}{r}.38 \\
(.34)\end{array}$ & & $\begin{array}{r}.33 \\
(.32)\end{array}$ & & $\begin{array}{r}.51 \\
(.29)\end{array}$ & $*$ \\
\hline Ratio, enrollment to population, FY1990 & $\begin{array}{r}192.1 \\
(114.4)\end{array}$ & $*$ & $\begin{array}{r}167.9 \\
(117.9)\end{array}$ & & $\begin{array}{r}126.6 \\
(112.9)\end{array}$ & & $\begin{array}{r}261.2 \\
(120.2)\end{array}$ & $* *$ \\
\hline Median family income (in ‘000), 1990 & $\begin{array}{l}-.48 \\
(.66)\end{array}$ & & $\begin{array}{r}-.41 \\
(.67)\end{array}$ & & $\begin{array}{l}-.33 \\
(.67)\end{array}$ & & $\begin{array}{r}.41 \\
(.75)\end{array}$ & \\
\hline Percentage of revenue from state aid, FY1984 & $\begin{array}{r}71.2 \\
(54.4)\end{array}$ & & $\begin{array}{r}68.3 \\
(51.3)\end{array}$ & & $\begin{array}{r}67.7 \\
(47.8)\end{array}$ & & $\begin{array}{r}54.9 \\
(52.5)\end{array}$ & \\
\hline Percentage increase in state aid, FY1981-84 & $\begin{array}{r}6.2 \\
(17.0)\end{array}$ & & $\begin{array}{r}7.7 \\
(17.9)\end{array}$ & & $\begin{array}{r}2.3 \\
(16.5)\end{array}$ & & $\begin{array}{r}10.5 \\
(16.4)\end{array}$ & \\
\hline Nonresidential share of property value, FY1990 & $\begin{array}{r}-72.7 \\
(42.3)\end{array}$ & $*$ & $\begin{array}{r}-59.3 \\
(43.2)\end{array}$ & & $\begin{array}{l}-46.1 \\
(44.6)\end{array}$ & & $\begin{array}{r}-107.1 \\
(42.8)\end{array}$ & $* *$ \\
\hline Dummy variable, member of regional school district & $\begin{array}{r}9.3 \\
(19.3)\end{array}$ & & $\begin{array}{r}5.8 \\
(19.5)\end{array}$ & & $\begin{array}{r}6.1 \\
(17.9)\end{array}$ & & $\begin{array}{r}18.4 \\
(18.8)\end{array}$ & \\
\hline Dummy variable, member of regional high school & $\begin{array}{r}7.2 \\
(17.5)\end{array}$ & & $\begin{array}{r}9.6 \\
(17.9)\end{array}$ & & $\begin{array}{r}7.9 \\
(17.5)\end{array}$ & & $\begin{array}{r}4.6 \\
(17.0)\end{array}$ & \\
\hline Percent of adult residents with college education, 1990 & $\begin{array}{l}168.2 \\
(67.9)\end{array}$ & $* *$ & $\begin{array}{l}166.7 \\
(68.2)\end{array}$ & $* *$ & $\begin{array}{l}156.5 \\
(71.2)\end{array}$ & $* *$ & $\begin{array}{r}95.0 \\
(68.8)\end{array}$ & \\
\hline Effective property tax rate, FY1980 & & & $\begin{array}{r}-159.7 \\
(556.5)\end{array}$ & & $\begin{array}{r}-102.8 \\
(566.0)\end{array}$ & & & \\
\hline $\begin{array}{l}\text { Dummy variable, required one year of initial levy } \\
\text { reductions, FY1982 }\end{array}$ & & & $\begin{array}{r}-7.7 \\
(8.2)\end{array}$ & & $\begin{array}{r}-6.4 \\
(8.8)\end{array}$ & & & \\
\hline $\begin{array}{l}\text { Dummy variable, required two years of initial levy } \\
\text { reductions, FY1982-83 }\end{array}$ & & & $\begin{array}{r}-.10 \\
(13.4)\end{array}$ & & $\begin{array}{r}-3.1 \\
(14.6)\end{array}$ & & & \\
\hline $\begin{array}{l}\text { Dummy variable, required three years of initial levy } \\
\text { reductions, FY1982-84 }\end{array}$ & & & $\begin{array}{l}-12.2 \\
(18.7)\end{array}$ & & $\begin{array}{l}-14.0 \\
(19.8)\end{array}$ & & & \\
\hline $\begin{array}{l}\text { Excess spending per pupil (required>actual spending), } \\
\text { FY1994 } \\
\text { Excess capacity as a percentage of levy limit, FY1989 }\end{array}$ & & & & & $\begin{array}{r}5.5 \\
(29.8) \\
-1.6 \\
(260.6)\end{array}$ & & & \\
\hline $\begin{array}{l}\text { Dummy variable, at levy limit and no overrides, } \\
\text { FY1989 } \\
\text { Dummy variable, passed override(s) prior to FY1990 }\end{array}$ & & & & & $\begin{array}{r}4.0 \\
(8.2) \\
27.0 \\
(13.4)\end{array}$ & $* *$ & & \\
\hline Constant & $\begin{array}{r}-160.8 \\
(52.0)\end{array}$ & $* *$ & $\begin{array}{r}-158.1 \\
(54.7)\end{array}$ & $* *$ & $\begin{array}{r}-156.8 \\
(52.8)\end{array}$ & $* *$ & $\begin{array}{r}-154.0 \\
(51.3)\end{array}$ & $* *$ \\
\hline $\begin{array}{l}\text { Adjusted R-squared } \\
\text { Number of observations }\end{array}$ & $\begin{array}{r}.42 \\
155\end{array}$ & & $\begin{array}{r}.43 \\
155\end{array}$ & & $\begin{array}{r}.46 \\
155\end{array}$ & & $\begin{array}{r}.45 \\
155\end{array}$ & \\
\hline
\end{tabular}

Notes: Numbers in parentheses are robust standard errors. * Significantly different from zero with 90 percent confidence. ** Significantly different from zero with 95 percent confidence. Regressions include only communities that are at their levy limit. Equation (1) is base equation. Equation (2) additionally includes early 1980s Proposition 21/2 variables. Equation (3) additionally includes late 1980s Proposition 21/2 variables. Equation (4) includes endogenous population changes. Bold variable is endogenous. Instruments include the demand shifters from the demand equation in Table 2 (i.e., the combined math and reading MEAP test scores and dummy variables for the Boston metro area and the suburban ring) plus the quantity and pupil shifters (i.e., the lagged permits in 1989 per 1990 housing units and the percentage of population less than 5 years old in 1990). 
Table 6

Variable List and Means of National School District-Level Sample $\mathrm{N}=11,565$

\begin{tabular}{|c|c|c|c|c|}
\hline Variable & Mean & Std. Dev. & Min. & Max. \\
\hline \multicolumn{5}{|l|}{ Spending and Revenue Variables of School Districts: } \\
\hline Total expenditures per pupil, SY $89 / 90$ & 5,131 & 1,979 & 1,176 & 19,682 \\
\hline State and federal revenue per pupil, SY $89 / 90$ & 2,377 & 1,121 & 26 & 12,563 \\
\hline \\
\hline $\begin{array}{l}\text { Developed residential land as percentage of total developable } \\
\text { non-industrial land, 1991-1993 }\end{array}$ & 0.11 & 0.21 & 0 & 0.999 \\
\hline Population density (persons per square kilometer), 1989 & 233 & 627 & 0.1 & 19,337 \\
\hline Number of schools in school agency & 6.0 & 15.8 & 1 & 998 \\
\hline Agency is independent local school district & 0.90 & 0.30 & 0 & 1 \\
\hline Agency is union component local school district & 0.10 & 0.30 & 0 & 1 \\
\hline Agency is supervisory union administrative center & 0.0026 & 0.051 & 0 & 1 \\
\hline Agency is regional education service agency (omitted) & 0.00026 & 0.016 & 0 & 1 \\
\hline Percentage students enrolled in special education school & 0.0010 & 0.010 & 0 & 0.45 \\
\hline Percentage students enrolled in vocational schools & 0.00061 & 0.0094 & 0 & 0.29 \\
\hline Percentage students enrolled in other/alternative school & 0.00090 & 0.011 & 0 & 0.60 \\
\hline Percentage children speak English not well & 0.0081 & 0.017 & 0 & 0.35 \\
\hline Percentage children below poverty line & 0.17 & 0.12 & 0 & 0.95 \\
\hline Percentage children at risk (e.g., divorced parents) & 0.031 & 0.042 & 0 & 0.46 \\
\hline District primarily serves central city of large MSA* & 0.0020 & 0.045 & 0 & 1 \\
\hline District primarily serves suburbs of large MSA* & 0.038 & 0.19 & 0 & 1 \\
\hline District primarily serves central city of medium sized MSA * & 0.011 & 0.10 & 0 & 1 \\
\hline District primarily serves suburbs of medium sized MSA * & 0.11 & 0.31 & 0 & 1 \\
\hline District primarily serves central city of small MSA * & 0.014 & 0.12 & 0 & 1 \\
\hline District primarily serves suburbs of small MSA * & 0.070 & 0.26 & 0 & 1 \\
\hline District primarily serves Non-MSA location * & 0.59 & 0.49 & 0 & 1 \\
\hline \multicolumn{5}{|l|}{ Demographics of Residents of School District: } \\
\hline Homeownership rate, 1990 & 0.75 & 0.10 & 0 & 1 \\
\hline Homeownership rate $>50$ percent & 0.97 & 0.16 & 0 & 1 \\
\hline Median household income, 1990 & 28,012 & 11,237 & 5,599 & 142,211 \\
\hline Gini coefficient, 1990 & 0.39 & 0.045 & 0.21 & 0.62 \\
\hline Percentage households with children $(<18), 1990$ & 0.38 & 0.072 & 0.028 & 0.90 \\
\hline Percentage households with age $>65,1990$ & 0.14 & 0.051 & 0.00071 & 0.71 \\
\hline Percentage households with age $>75,1990$ & 0.062 & 0.028 & 0 & 0.30 \\
\hline Percentage households with age $>85,1990$ & 0.014 & 0.0096 & 0 & 0.094 \\
\hline Percentage college educated residents over 25, 1990 & 0.14 & 0.096 & 0 & 0.81 \\
\hline Difference $\%$ non-whites among children in school age & & & & 0.67 \\
\hline g elderly residents over 65 & $\begin{array}{r}0.055 \\
014\end{array}$ & $\begin{array}{r}0.084 \\
016\end{array}$ & $\begin{array}{r}-0.50 \\
0\end{array}$ & $\begin{array}{l}0.67 \\
0.69\end{array}$ \\
\hline Percentage Black population, 1990 & 0.049 & 0.12 & 0 & $\begin{array}{l}0.09 \\
0.99\end{array}$ \\
\hline Percentage Asian population, 1990 & 0.0064 & 0.014 & 0 & 0.24 \\
\hline Percentage Hispanic population, 1990 & 0.037 & 0.10 & 0 & 1 \\
\hline
\end{tabular}

Notes, marked with asterisks: MSA is defined as large if the population size is > 1 million residents, as medium sized if the population size is between 250,000 and 1,000,000, and as small if the population size is smaller than 250,000 residents. Data source: School District Data Book (SDDB), School Year 1989/90. National Center for Education Statistics, Office of Educational Research and Improvement, U.S. Department of Education. 
Table 7

\section{School Spending Regression Results without MSA Location Type Controls}

\section{Dependent Variables: Log of Total School Expenditures per Pupil, SY 1989/90}

\begin{tabular}{|c|c|c|c|c|c|c|c|c|c|}
\hline Explanatory Variable & (1) & & (2) & & (3) & & (4) & (5) & \\
\hline Percentage developed land, 1992 & $\begin{array}{r}.16 \\
(.019)\end{array}$ & $* *$ & $\begin{array}{r}.016 \\
(.061)\end{array}$ & & $\begin{array}{l}-.051 \\
(.069)\end{array}$ & & $\begin{array}{l}-.016 \\
(.068)\end{array}$ & $\begin{array}{l}-.026 \\
(.066)\end{array}$ & \\
\hline Homeownership dummy, 1990 & $\begin{array}{r}-.032 \\
(.019)\end{array}$ & & $\begin{array}{r}-.086 \\
(.033)\end{array}$ & $* *$ & $\begin{array}{r}-.084 \\
(.033)\end{array}$ & $*$ & $\begin{array}{l}-.070 * \\
(.033)\end{array}$ & $\begin{array}{l}-.065 \\
(.033)\end{array}$ & $*$ \\
\hline $\begin{array}{l}\text { Percentage developed land } \mathrm{x} \\
\text { Homeownership dummy }\end{array}$ & & & $\begin{array}{r}.14 \\
(.054)\end{array}$ & $* *$ & $\begin{array}{r}.13 \\
(.054)\end{array}$ & $*$ & $\begin{array}{l}.13 * \\
(.055)\end{array}$ & $\begin{array}{r}.13 \\
(.055)\end{array}$ & $*$ \\
\hline Percentage age 65 or older, 1990 & $\begin{array}{r}.18 \\
(.088)\end{array}$ & $*$ & $\begin{array}{r}.19 \\
(.088)\end{array}$ & $*$ & $\begin{array}{r}.14 \\
(.089)\end{array}$ & & & & \\
\hline $\begin{array}{l}\text { Percentage developed land } \mathrm{x} \\
\text { Percentage age } 65 \text { or older }\end{array}$ & & & & & $\begin{array}{r}.48 \\
(.24)\end{array}$ & $*$ & & & \\
\hline Percentage age 75 or older, 1990 & & & & & & & $\begin{array}{r}-.22 \\
(.14)\end{array}$ & & \\
\hline $\begin{array}{l}\text { Percentage developed land } x \\
\text { Percentage age } 75 \text { or older }\end{array}$ & & & & & & & $\begin{array}{r}.71 \\
(.47)\end{array}$ & & \\
\hline Percentage age 85 or older, 1990 & & & & & & & & $\begin{array}{l}-1.8 \\
(.32)\end{array}$ & $* *$ \\
\hline $\begin{array}{l}\text { Percentage developed land } x \\
\text { Percentage age } 85 \text { or older }\end{array}$ & & & & & & & & $\begin{array}{r}3.9 \\
(1.6)\end{array}$ & $*$ \\
\hline Population density in '000, 1989 & $\begin{array}{r}-.019 \\
(.0049)\end{array}$ & $* *$ & $\begin{array}{r}-.011 \\
(.0055)\end{array}$ & & $\begin{aligned}-.011 \\
(.0054)\end{aligned}$ & $*$ & $\begin{array}{l}-.012 \\
(.0054)\end{array}$ & $\begin{array}{r}-.012 \\
(.0054)\end{array}$ & $*$ \\
\hline MSA location type controls & No & & No & & No & & No & No & \\
\hline Other controls ${ }^{a)}$ & Yes & & Yes & & Yes & & Yes & Yes & \\
\hline Adjusted R-squared & .59 & & .59 & & .59 & & .59 & .59 & \\
\hline Number of observations & 11,565 & & 11,565 & & 11,565 & & 11,565 & 11,565 & \\
\hline
\end{tabular}

Notes: Numbers in parentheses are robust standard errors. * Significantly different from zero with 95 percent confidence. ** Significantly different from zero with 99 percent confidence. ${ }^{a)}$ All regressions control for demographic characteristics of the residents of the school district, school district specific characteristics, and state fixed effects (see the Appendix Table for a full list of control variables). "Percentage developed" is defined as percentage of residential developed land divided by the total non-industrial developable land in a school district in 1992. The regression sample excludes states with full school finance equalization (California, New Mexico, and Hawaii). Consistent with theory, all interaction effects reported in Table 7 are completely statistically insignificant for the sample of school districts with full school finance equalization. Results are not appreciably different when population density is excluded as a control variable. The statistical significance levels of the interaction effects overall slightly improve. If the log of state and federal revenue per pupil is included as an additional control variable results remain similar, with all interaction effects reported in Table 7 having the predicted sign and being statistically significantly different from zero with at least 90 percent confidence. The log of state and federal revenue per pupil is not included in the base specification because it is arguably endogenous. 
Table 8

\section{School Spending Regression Results with MSA Location Type Controls}

\section{Dependent Variables: Log of Total School Expenditures per Pupil, SY 1989/90}

\begin{tabular}{|c|c|c|c|c|c|c|c|c|c|c|}
\hline Explanatory Variable & (1) & & (2) & & (3) & & (4) & & $(5)$ & \\
\hline Percentage developed land , 1992 & $\begin{array}{r}.14 \\
(.019)\end{array}$ & & $\begin{array}{l}-.012 \\
(.061)\end{array}$ & & $\begin{aligned}-.11 \\
(.069)\end{aligned}$ & & $\begin{array}{l}-.069 \\
(.067)\end{array}$ & & $\begin{aligned}-.072 \\
(.065)\end{aligned}$ & \\
\hline Homeownership dummy, 1990 & $\begin{array}{l}-.032 \\
(.019)\end{array}$ & & $\begin{array}{l}-.089 \\
(.033)\end{array}$ & $* *$ & $\begin{array}{l}-.086 \\
(.033)\end{array}$ & $* *$ & $\begin{array}{l}-.074 \\
(.033)\end{array}$ & $*$ & $\begin{array}{l}-.071 \\
(.033)\end{array}$ & $*$ \\
\hline $\begin{array}{l}\text { Percentage developed land } \mathrm{x} \\
\text { Homeownership dummy }\end{array}$ & & & $\begin{array}{r}.15 \\
(.054)\end{array}$ & $* *$ & $\begin{array}{r}.14 \\
(.054)\end{array}$ & $*$ & $\begin{array}{r}.14 \\
(.055)\end{array}$ & $*$ & $\begin{array}{r}.14 \\
(.055)\end{array}$ & $*$ \\
\hline Percentage age 65 or older, 1990 & $\begin{array}{r}.14 \\
(.089)\end{array}$ & & $\begin{array}{r}.15 \\
(.089)\end{array}$ & & $\begin{array}{r}.082 \\
(.090)\end{array}$ & & & & & \\
\hline $\begin{array}{l}\text { Percentage developed land } x \\
\text { Percentage age } 65 \text { or older }\end{array}$ & & & & & $\begin{array}{r}.68 \\
(.24)\end{array}$ & $* *$ & & & & \\
\hline Percentage age 75 or older, 1990 & & & & & & & $\begin{array}{r}-.31 \\
(.14)\end{array}$ & & & \\
\hline $\begin{array}{l}\text { Percentage developed land } x \\
\text { Percentage age } 75 \text { or older }\end{array}$ & & & & & & & $\begin{array}{r}1.1 \\
(.47)\end{array}$ & $*$ & & \\
\hline Percentage age 85 or older, 1990 & & & & & & & & & $\begin{array}{l}-1.9 \\
(.32)\end{array}$ & $* *$ \\
\hline $\begin{array}{l}\text { Percentage developed land } x \\
\text { Percentage age } 85 \text { or older }\end{array}$ & & & & & & & & & $\begin{array}{r}5.0 \\
(1.5)\end{array}$ & $* *$ \\
\hline Population density in '000, 1989 & $\begin{array}{r}-.021 \\
(.0049)\end{array}$ & $* *$ & $\begin{array}{r}-.013 \\
(.0054)\end{array}$ & $*$ & $\begin{array}{r}-.013 \\
(.0053)\end{array}$ & $*$ & $\begin{array}{r}-.014 \\
(.0053)\end{array}$ & $* *$ & $\begin{array}{r}-.014 \\
(.0053)\end{array}$ & $*$ \\
\hline MSA location type controls & Yes & & Yes & & Yes & & Yes & & Yes & \\
\hline Other controls ${ }^{a)}$ & Yes & & Yes & & Yes & & Yes & & Yes & \\
\hline Adjusted R-squared & .59 & & .59 & & .59 & & .59 & & .59 & \\
\hline Number of observations & 11,565 & & 11,565 & & 11,565 & & 11,565 & & 11,565 & \\
\hline
\end{tabular}

Notes: Numbers in parentheses are robust standard errors. * Significantly different from zero with 95 percent confidence. ** Significantly different from zero with 99 percent confidence. ${ }^{a)}$ All regressions control for demographic characteristics of the residents of the school district, school district specific characteristics, and state fixed effects (see the Appendix Table for a full list of control variables). "Percentage developed" is defined as percentage of residential developed land divided by the total non-industrial developable land in a school district in 1992. The regression sample excludes states with full school finance equalization (California, New Mexico, and Hawaii). Consistent with theory, all interaction effects reported in Table 7 are completely statistically insignificant for the sample of school districts with full school finance equalization. Results are not appreciably different when population density is excluded as a control variable. The statistical significance levels of the interaction effects slightly improve. If the log of state and federal revenue per pupil is included as an additional control variable results remain similar, with all interaction effects reported in Table 7 having the predicted sign and being statistically significantly different from zero with at least 95 percent confidence. The log of state and federal revenue per pupil is not included in the base specification because it is arguably endogenous. 
Table 9

Quantitative Effects for Representative School Districts with Homeowner-Majorities

\begin{tabular}{|c|c|c|c|c|}
\hline & & $\begin{array}{l}\text { Little developed } \\
\text { school district } \\
\text { (75 } \\
6.6 \% \text { dercentile: } \\
\text { th }\end{array}$ & $\begin{array}{l}\text { Highly developed } \\
\text { school district } \\
\left(95^{\text {th }} \text { percentile: }\right. \\
68.1 \% \text { developed })\end{array}$ & $\begin{array}{c}\Delta \text { Highly developed } \\
\text { versus little } \\
\text { developed school } \\
\text { district }\end{array}$ \\
\hline Change & Specification & $\begin{array}{l}\text { Percentage } \\
\text { change in } \\
\text { spending per } \\
\text { pupil } \\
\text { (1) }\end{array}$ & $\begin{array}{l}\text { Percentage } \\
\text { change in } \\
\text { spending per } \\
\text { pupil } \\
\text { (2) }\end{array}$ & $\begin{array}{l}\text { Additional spending } \\
\text { per pupil in highly } \\
\text { developed district } \\
\text { due to change } \\
(3)=(2)-(1)\end{array}$ \\
\hline $\begin{array}{l}\text { Effect of percentage developed } \\
\text { residential land on school } \\
\text { expenditures per pupil (little versus } \\
\text { highly developed district) }\end{array}$ & Table 8 (1) & Baseline & $10.7 \%$ & $10.7 \%$ \\
\hline $\begin{array}{l}\text { Majority of housing tenure in school } \\
\text { district changes from owner- } \\
\text { occupation to renter-occupation }\end{array}$ & $\begin{array}{l}\text { Table } 7(2) \\
\text { Table } 8(2)\end{array}$ & $\begin{array}{l}8.1 \% \\
8.3 \%\end{array}$ & $\begin{array}{l}-1.5 \% \\
-1.6 \%\end{array}$ & $\begin{array}{l}-9.6 \% \\
-10.0 \%\end{array}$ \\
\hline $\begin{array}{l}\text { Elderly population (over } 65 \text { ) } \\
\text { increases by } 1 \text { standard deviation }\end{array}$ & $\begin{array}{l}\text { Table } 7(3) \\
\text { Table } 8(3)\end{array}$ & $\begin{array}{l}1.0 \% \\
0.8 \%\end{array}$ & $\begin{array}{l}1.8 \% \\
2.1 \%\end{array}$ & $\begin{array}{l}+0.8 \% \\
+1.4 \%\end{array}$ \\
\hline $\begin{array}{l}\text { Elderly population (over } 75 \text { ) } \\
\text { increases by } 1 \text { standard deviation }\end{array}$ & $\begin{array}{l}\text { Table } 7(4) \\
\text { Table } 8(4)\end{array}$ & $\begin{array}{l}-0.4 \% \\
-0.5 \%\end{array}$ & $\begin{array}{l}1.1 \% \\
1.7 \%\end{array}$ & $\begin{array}{l}+1.5 \% \\
+2.2 \% \\
\end{array}$ \\
\hline $\begin{array}{l}\text { Elderly population (over } 85 \text { ) } \\
\text { increases by } 1 \text { standard deviation }\end{array}$ & $\begin{array}{l}\text { Table } 7(5) \\
\text { Table } 8(5)\end{array}$ & $\begin{array}{l}-2.1 \% \\
-2.2 \%\end{array}$ & $\begin{array}{l}0.6 \% \\
1.4 \% \\
\end{array}$ & $\begin{array}{l}+2.7 \% \\
+3.5 \% \\
\end{array}$ \\
\hline
\end{tabular}

Notes: The total average school spending per pupil in the regression samples is $\$ 5,131$. "Percentage developed" is defined as percentage of residential developed land divided by the total non-industrial developable land in a school district in 1992. The baseline is a representative school district with a homeowner-majority. That is, quantitative effects are measured at the regression sample averages except that a homeowner-majority is assumed rather than the sample average of the homeownership dummy variable $(=0.97) .{ }^{*}$ The quantitative effects reported in columns (1) and (2) do not always precisely add up to the differential percentage value reported in column (3) due to rounding errors. 
Appendix:

School Spending Regression Results for Base Specification, National Sample Dependent Variable: Log of Total School Expenditures per Pupil, School Year 1989/90

\begin{tabular}{|c|c|c|}
\hline Explanatory Variable & All Distric & \\
\hline Percentage developed land, 1992 & $\begin{array}{r}.16 \\
(.019)\end{array}$ & $* *$ \\
\hline Homeownership dummy (equals 1 if homeownership rate > 50 percent), 1990 & $\begin{array}{r}-.032 \\
(.019)\end{array}$ & \\
\hline Log of median household income, 1990 & $\begin{array}{r}.066 \\
(.023)\end{array}$ & ** \\
\hline Gini coefficient & $\begin{array}{r}-.21 \\
(.11)\end{array}$ & $*$ \\
\hline Percentage of households with children & $\begin{array}{r}-.27 \\
(.073)\end{array}$ & $* *$ \\
\hline Percentage of population, age 65 and up & $\begin{array}{r}.18 \\
(.088)\end{array}$ & * \\
\hline Percentage of children who "speak English not well" & $\begin{array}{r}.52 \\
(.23)\end{array}$ & $* *$ \\
\hline Percentage of children below poverty & $\begin{array}{r}.41 \\
(.048)\end{array}$ & $* *$ \\
\hline Percentage of children at risk & $\begin{array}{r}-.34 \\
(.11)\end{array}$ & $* *$ \\
\hline Percentage of adult residents with a college education & $\begin{array}{r}.69 \\
(.046)\end{array}$ & $* *$ \\
\hline $\begin{array}{l}\text { Difference \% non-whites among children in school age (5-19) - } \\
\% \text { non-whites among elderly residents over } 65\end{array}$ & $\begin{array}{r}.15 \\
(.057)\end{array}$ & $* *$ \\
\hline Ethnic fractionalization, 1990 & $\begin{array}{r}-.0054 \\
(.037)\end{array}$ & \\
\hline Percentage Black population & $\begin{array}{r}.072 \\
(.039)\end{array}$ & \\
\hline Percentage Asian population & $\begin{array}{r}-.19 \\
(.25)\end{array}$ & \\
\hline Percentage Hispanic population & $\begin{array}{r}.012 \\
(.048)\end{array}$ & \\
\hline Number of schools in school agency & $\begin{array}{r}-.0023 \\
(.00031)\end{array}$ & $* *$ \\
\hline Number of schools in school agency, squared (in '000) & $\begin{array}{r}.0026 \\
(.00058)\end{array}$ & $* *$ \\
\hline Percentage of students enrolled in special education schools & $\begin{array}{r}.18 \\
(.26)\end{array}$ & \\
\hline Percentage of students enrolled in vocational schools & $\begin{array}{r}.25 \\
(.18)\end{array}$ & \\
\hline Percentage of students enrolled in other schools/alternative schools & $\begin{array}{r}-.078 \\
(.39)\end{array}$ & \\
\hline Agency is independent local school district, SY $89 / 90$ & $\begin{array}{r}-.13 \\
(.050)\end{array}$ & $*$ \\
\hline Agency is local school district component of supervisory union, SY 89/90 & $\begin{array}{r}-.12 \\
(.051)\end{array}$ & $*$ \\
\hline $\begin{array}{l}\text { Agency is supervisory union administration center or a county superintendent, } \\
\text { SY } 89 / 90\end{array}$ & $\begin{array}{r}-.19 \\
(.059)\end{array}$ & ** \\
\hline Population density in '000, 1989 & $\begin{array}{r}-.019 \\
(.0049)\end{array}$ & $* *$ \\
\hline State Fixed Effects & Yes & \\
\hline Constant & $\begin{array}{r}8.0 \\
(.26)\end{array}$ & $* *$ \\
\hline Adjusted R-squared & .59 & \\
\hline Number of observations & 11,565 & \\
\hline
\end{tabular}

Notes: Numbers in parentheses are robust standard errors. * Significantly different from zero with $95 \%$ confidence. ${ }^{* *}$ Significantly different from zero with $99 \%$ confidence. 